\title{
CANADA: Report on the Observance of Standards and Codes
}




\section{INTERNATIONAL MONETARY FUND}

\section{CANADA}

\section{Report on the Observance of Standards and Codes}

February 2014

This report on the observance of standards and codes on Canada was prepared by a staff team of the International Monetary Fund as background documentation for the periodic consultation with the member country. It is based on the information available at the time it was completed on January 10, 2014. The views expressed in this document are those of the staff team and do not necessarily reflect the views of the government of Canada or the Executive Board of the IMF.

The policy of publication of staff reports and other documents by the IMF allows for the deletion of market-sensitive information.

Copies of this report are available to the public from

International Monetary Fund $\bullet$ Publication Services

$70019^{\text {th }}$ Street, N.W. $\bullet$ Washington, D.C. 20431

Telephone: (202) 623-7430 • Telefax: (202) 623-7201

E-mail: publications@imf.org Internet: http://www.imf.org

Price: $\$ 18.00$ a copy

\section{International Monetary Fund Washington, D.C.}




\section{INTERNATIONAL MONETARY FUND}

\section{CANADA}

\section{REPORT ON OBSERVANCE OF STANDARDS AND}

January 2014

\section{CODES}

Prepared By

Monetary and Capital

Markets Department
This report was prepared in the context of a standards assessment mission in Canada during June and September 2013, and overseen by the Monetary and Capital Markets Department, IMF. 


\section{CONTENTS}

GLOSSARY

BASEL CORE PRINCIPLES FOR EFFECTIVE BANKING SUPERVISION $\underline{5}$

A. Summary __ $\underline{5}$

B. Introduction __ $\underline{5}$

C. Information and Methodology Used for Assessment ___ $\underline{6}$

D. Key Findings___ $\underline{6}$

E. Recommendations__ 16

F. Authorities' Response _ـ 19

ASSESSMENT OF INSURANCE CORE PRINCIPLES___ $\underline{\mathbf{2 0}}$

A. Summary _ـ $\underline{20}$

B. Introduction and Scope _ $\underline{20}$

C. Market and Institutional Setting___ 21

D. Key Findings__ $\underline{25}$

E. Recommendations__ $\underline{36}$

F. Authorities' Response __ $4 \underline{40}$

ASSESSMENT OF THE IOSCO PRINCIPLES AND OBJECTIVES OF SECURITIES REGULATION $\underline{41}$
A. Summary $\underline{41}$
B. Introduction and Scope $\underline{42}$
C. Institutional Setting 43
D. Market Structure $\underline{45}$
E. Key Findings $\underline{48}$
F. Recommendations $\underline{60}$
G. Authorities' Response $\underline{63}$

\section{TABLES}

1. Summary of Compliance with BCPs $\underline{8}$

2. Recommendations to Improve Observance of the BCPs _ 16

3. Summary of Compliance with the ICPs__ $\underline{26}$

4. Recommendations to Improve Observance of the ICPs__

5. Summary Table of Implementation of the IOSCO Principles __ $\underline{50}$

6. Recommendation for the Implementation of the IOSCO Principles ___ 


\section{Glossary}

\begin{tabular}{|c|c|}
\hline AMF & Autorité des Marchés Financiers \\
\hline AML/CFT & Anti-Money Laundering and Combating the Financing of Terrorism \\
\hline ASB & Accounting Standards Board \\
\hline ASC & Alberta Securities Commission \\
\hline ATS & Alternative Trading System \\
\hline $\mathrm{BCBS}$ & Basel Committee for Banking Supervision \\
\hline $\mathrm{BCSC}$ & British Columbia Securities Commission \\
\hline BDR & Bureau de Décision et de Révision \\
\hline CAD & Chambre de l'assurance de dommages \\
\hline Canadian AS & Canadian Accounting Standards \\
\hline CCIR & Canadian Council of Insurance Regulators \\
\hline CDCC & Canadian Derivatives Clearing Corporation \\
\hline CDIC & Canada Deposit Insurance Corporation \\
\hline CDS & Canada Depository for Securities \\
\hline CEO & Chief Executive Officer \\
\hline CIA & Canadian Institute of Actuaries \\
\hline CIS & Collective Investment Schemes \\
\hline CISRO & Canadian Insurance Services Regulatory Organizations \\
\hline CLHIA & Canadian Life and Health Insurance Association \\
\hline $\mathrm{CMHC}$ & Canada Mortgage and Housing Corporation \\
\hline CPAB & Canadian Public Accountability Board \\
\hline CSA & Canadian Securities Administrators \\
\hline CSF & Chambre de la Securité Financière \\
\hline DA & An Act respecting the Distribution of Financial Products and Services \\
\hline EMDs & Exempt Market Dealers \\
\hline FATF & Financial Action Task Force \\
\hline FCAC & Financial Consumer Agency of Canada \\
\hline FINTRAC & Financial Transactions and Reports Analysis Centre of Canada \\
\hline FIs & Financial Institutions \\
\hline FISC & Financial Institutions Supervisory Committee \\
\hline FRFIs & Federally Regulated Financial Institutions \\
\hline FRIs & Federally Regulated Insurers \\
\hline FSAP & Financial Sector Assessment Program \\
\hline FSCO & The Financial Services Commission of Ontario \\
\hline Government & Government of Canada \\
\hline GWL & The Great West Life Assurance Company \\
\hline GWS & Group-wide Supervisor \\
\hline IA & An Act respecting Insurance (Québec) \\
\hline
\end{tabular}




\begin{tabular}{|l|l|}
\hline ICAAP & Internal Capital Adequacy Assessment Process \\
\hline IDs & Investment Dealers \\
\hline IFRS & International Financial Reporting Standards \\
\hline IIROC & Investment Industry Regulatory Organization of Canada \\
\hline ILS & insurance linked securities \\
\hline IOSCO & International Organization of Securities Commission \\
\hline IRC & Independent Review Committee \\
\hline JFFMR & Joint Forum of Financial Market Regulators \\
\hline L\&H & Life and Health \\
\hline LTV & Loan-to-value \\
\hline MFDA & Mutual Fund Dealers Association of Canada \\
\hline MFEQ & Minister of Finance and the Economy \\
\hline MGAs & Managing General Agencies \\
\hline MoU & Memorandum of Understanding \\
\hline MX & Montreal Exchange \\
\hline OIA & Insurance Act of Ontario \\
\hline ORSA & Own Risk and Solvency Assessment \\
\hline OSC & Ontario Securities Commission \\
\hline OSFI & Office of the Superintendent of Financial Institutions \\
\hline P\&C & Property and Casualty \\
\hline PACICC & Property and Casualty Insurance Compensation Corporation \\
\hline RIBO & Registered Insurance Brokers of Ontario \\
\hline RS & Market Regulation Services Inc. \\
\hline SLF & Sun Life Financial Inc \\
\hline SROs & Self-regulatory Organizations \\
\hline TSX & Toronto Stock Exchange \\
\hline UMIR & Universal Market Integrity Rules \\
\hline
\end{tabular}




\section{BASEL CORE PRINCIPLES FOR EFFECTIVE BANKING SUPERVISION}

\section{A. Summary}

1. Canada has a very high level of compliance with the Basel Core Principles for Effective Banking Supervision (BCPs). In response to the challenges and structure of its market, the Canadian banking supervisor (OSFI) has developed and is a strong proponent of risk based, proportionate, supervisory practices and applies a "close touch" approach to its supervised entities. The supervisory approach is well structured, forward looking and maintained on as dynamic a basis as possible. Entry to the Canadian market is subject to demanding prudential entry standards. At the same time there are a small number of potential frailties within the system. Although operational independence is clearly in evidence in OSFI's practices and decision-making the Bank Act could better distinguish OSFI's and the Superintendent's prudential responsibilities from those of the Minister. In a more administrative context, OSFI could sharpen its existing reporting and notification obligations in the areas of acquisition and ownership of banks, related party transactions and large exposures.

\section{B. Introduction}

2. This assessment of the Basel Core Principles for Effective Supervision (BCP) is part of the 2013 FSAP update for Canada. The assessment of OSFI was conducted during an IMF mission that visited Canada from June 12 to $28,2013 .{ }^{1}$ Canada is among the first countries to be assessed against the BCP methodology issued by the Basel Committee on Banking Supervision (BCBS) in September 2012.

\section{An assessment of the effectiveness of banking supervision requires a review of the} legal framework and detailed examination of the policies and practices of the institutions responsible for banking regulation and supervision. In line with the BCP methodology, the assessment focused on OSFI as the supervisor of the banking system and did not cover the specificities of regulation and supervision of other financial intermediaries at the federal or provincial level.

\section{This Report on the Observance of Standards and Codes (ROSC) summarizes the} findings and recommendations of the assessment, and should be read in the context of the accompanying FSAP documents. The Financial System Stability Assessment (FSSA) and accompanying notes and ROSCs provide a complete picture of the institutional setting and market structure. These FSAP documents also cover the preconditions for effective banking supervision,

\footnotetext{
${ }^{1}$ The assessment team comprised Katharine Seal (IMF) and Heidi Richards (Australian Prudential Regulation Authority, Consultant).
} 
including a description of the macroeconomic framework, financial stability policy formulation, public infrastructure, crisis management, recovery and resolution, the adequacy of systemic protection (for public safety net); and market discipline.

\section{Information and Methodology Used for Assessment}

5. The Canadian authorities chose to be assessed and rated against both Essential Criteria and Additional Criteria. To assess compliance, the BCP Methodology uses a set of essential and additional criteria for each principle and the assessment of compliance is made on a qualitative basis. The last BCP assessment was conducted in 2000, and a targeted assessment of four principles was carried out in 2008. It should be noted that the ratings assigned during this assessment are not directly comparable to previous assessments which were conducted under a separate iteration of the methodology, which was revised in 2006 and again in 2012. In particular the revised BCP have a heightened focus on risk management and strengthen the requirements for supervisors, the approaches to supervision and supervisors' expectations of banks.

6. The assessment team reviewed the framework of laws, rules, and guidance and held extensive meetings with officials of OSFI, and additional meetings with the BoC, Department of Finance, auditing firms, and banking sector participants. The authorities provided a comprehensive self-assessment of the CPs, as well as detailed responses to additional questionnaires, and facilitated access to supervisory documents and files, staff and systems.

7. The team received excellent cooperation from the authorities. The team extends its thanks to staff of the authorities, who facilitated comprehensive access to supervisory documents, staff and systems as well as extensive documentation and technical support, at a time when many other resource intensive projects related to domestic and global regulatory initiatives were underway.

\section{The standards were evaluated in the context of the Canadian financial system's} sophistication and complexity. The CPs must be capable of application to a wide range of jurisdictions whose banking sectors will inevitably include a broad spectrum of banks. To accommodate this breadth of application, a proportionate approach is adopted within the $\mathrm{CP}$, both in terms of the expectations on supervisors for the discharge of their own functions and in terms of the standards that supervisors impose on banks. An assessment of a country against the CPs must, therefore, recognize that its supervisory practices should be commensurate with the complexity, interconnectedness, size, and risk profile and cross-border operation of the banks being supervised. In other words, the assessment must consider the context in which the supervisory practices are applied. The concept of proportionality underpins all assessment criteria. For these reasons, an assessment of one jurisdiction will not be directly comparable to that of another.

\section{Key Findings}

9. Canada has a very high level of compliance with the Basel Core Principles for Effective Banking Supervision (BCPs). The Canadian banking system is recognized as having performed well 
during the turbulence of the financial crisis and subsequently. The system is highly concentrated in six domestic players, with only limited foreign presence in the market. In response to the challenges and structure of this market, the Canadian banking supervisor (OSFI) has developed and is a strong proponent of risk based, proportionate, supervisory practices and applies a "close touch" approach with its supervised entities who perceive OSFI as authoritative but accessible. Entry to the Canadian market is subject to demanding prudential entry standards and any new entrant to the market, whether domestic or foreign, has undergone an intensive process of gaining familiarity with OSFI's expectations and developing its relationship with the supervisor.

10. The legislative framework provides comprehensive powers and flexibility, but has the potential to undermine OSFI's independence. A strength of the Bank Act, which establishes wide ranging powers for OSFI, is that it must be updated at least every five years, ensuring it remains current. Nevertheless, although operational independence is clearly in evidence in OSFI's practices and decision-making the Bank Act could better distinguish OSFI's and the Superintendent's prudential responsibilities from those of the Minister. Amending the legislation to ensure that a veto, solely on prudential grounds, is securely in place regarding decisions that the Superintendent must make, such as those relating to change of control of a federally regulated bank or major acquisitions or investments made by such entities would provide due legal certainty as well as transparency of process.

\section{OSFI's mandate emphasizes an early intervention approach although it also works} within a risk tolerance framework that does not seek to deliver a zero failure regime. The protection of the depositor's interests is a central objective in OSFI's mandate and motivates OSFI's early intervention supervisory strategy. The supervisory approach is well structured, forward looking and maintained on as dynamic a basis as possible to ensure that risks in institutions are identified, prioritized and acted upon as soon as possible.

12. Although OSFI is equipped with a comprehensive range of supervisory powers, it does not resort to legal intervention quickly. Since OSFI practices close relationship supervision a rapid use of legal powers could be seen as counterproductive to the openness and effectiveness of that relationship. However, such a system requires the early identification of failure to meet minimum standards and puts a premium on maintaining direction, momentum and closure in resolving supervisory issues in a timely manner.

\section{OSFI adopts a close and cooperative approach in its relationships with other} authorities. OSFI's open and collaborative attitude has contributed significantly to the respect in which it is held by its international peers. Domestically, OSFI's cooperative approaches support the close network of federal authorities in identifying and seeking to mitigate prudential risks to the federal system. Notwithstanding the good federal level working relationships, however, some fragilities exist. For example, despite excellent cooperation between OSFI and FINTRAC in the field of AML/CFT, OSFI's inability to impose penalty fines with respect to any weaknesses that may exist in an institution's management of its money laundering/terrorist financing risk is a concern. Revision to the Bank Act would remedy the situation. Fragilities in the consistency and quality of communication 
with relevant provincial regulators also exist. A proactive approach to information sharing would be appropriate and fall within existing mandates.

\section{OSFI is responding proactively to the demands of the international regulatory reform} agenda and is an early adopter of many standards. By articulating its supervisory standards and expectations through the medium of guidelines, rather than legal regulations, OSFI has a great degree of nimbleness and flexibility which has enabled it to be proactive in its adoption of Basel 3 as well as the standard for D-SIBs. Guidelines, while not legally binding, are treated as such by firms not least due to OSFI's wide range of supervisory powers of intervention in the event that a guideline is breached.

\section{OSFI operates at a relatively principles-based level and does not tend to issue} extensive, detailed risk management guidance. While this approach is more flexible and potentially responsive to differing institutions and risks, as a world-leading regulator, OSFI could be expected to issue a comprehensive suite of risk management standards to be available to all banks, even if at a relatively high level or based largely on BCBS guidance.

\begin{tabular}{|c|c|}
\hline \multicolumn{2}{|r|}{ Table 1. Summary of Compliance with BCPs } \\
\hline Core Principle & Comment \\
\hline $\begin{array}{l}\text { 1. Responsibilities, } \\
\text { objectives and } \\
\text { powers }\end{array}$ & $\begin{array}{l}\text { OSFI has the sole legal mandate for the supervision of banks in Canada. As an } \\
\text { institution OSFI demonstrates a strong consciousness of its mandate and of } \\
\text { working within the scope of its mandate at all times. The Bank Act, the main } \\
\text { statute under which OSFI operates, provides OSFI with a wide range of powers } \\
\text { that are essential to the performance of effective supervision and provides the } \\
\text { framework within which OSFI sets and enforces the minimum prudential } \\
\text { standards. The mandatory five-year revision to the Bank Act provides a legal } \\
\text { framework with a ready capacity to be periodically updated to reflect the } \\
\text { demands of the financial system and expectations placed on supervisory } \\
\text { practice. }\end{array}$ \\
\hline $\begin{array}{l}\text { 2. Independence, } \\
\text { accountability, } \\
\text { resourcing and legal } \\
\text { protection for } \\
\text { supervisors }\end{array}$ & $\begin{array}{l}\text { OSFI is a government agency whose formal head is the Minister of Finance and } \\
\text { hence, is subject to some governmental disciplines. Despite this structure, } \\
\text { operational independence is clearly in evidence in OSFI's practices and decision- } \\
\text { making and is confirmed by all stakeholders including the industry. } \\
\text { Nevertheless, the Bank Act could better distinguish OSFI's and the } \\
\text { Superintendent's prudential responsibilities from those of the Minister, who } \\
\text { must naturally take a separate range of considerations into account. The } \\
\text { concern is to ensure that a veto on prudential grounds is securely in place } \\
\text { regarding decisions that the Superintendent must make, such as those relating } \\
\text { to change of control of a federally regulated bank or major acquisitions or } \\
\text { investments made by such entities. }\end{array}$ \\
\hline 3. Cooperation and & $\begin{array}{l}\text { Cohesive cooperation and collaboration are the keynotes of OSFI's relationships } \\
\text { with relevant authorities. Federal level cooperation is supported by a common }\end{array}$ \\
\hline
\end{tabular}




\begin{tabular}{|c|c|}
\hline collaboration & $\begin{array}{l}\text { desire among the agencies and authorities to assure the safety and soundness } \\
\text { of the Canadian financial system and its institutions. Cooperative arrangements } \\
\text { are well established over decades and proved to be responsive and effective } \\
\text { during the financial crisis. } \\
\text { Foreign authorities comment very favourably on the quality of their interactions } \\
\text { with OSFI. Moreover a number of regulatory authorities, both domestic and } \\
\text { foreign, have turned to OSFI for technical assistance to develop their skills, } \\
\text { confirming the degree of confidence invested in OSFI's practices and standards. } \\
\text { Nevertheless, there are weaknesses in the Canadian arrangements when } \\
\text { considering the relationship between the federal and provincial authorities. } \\
\text { Touch points with the provincial regulators are less well developed and } \\
\text { represent a potential frailty in an otherwise very well functioning system. } \\
\text { In the specific context of the BCP assessment, which is an assessment of the } \\
\text { federal level of supervision, it is important that there is full and free flow of } \\
\text { information to ensure that OSFI has access to all the information it needs to } \\
\text { carry out its mandate. }\end{array}$ \\
\hline 4. Perm & $\begin{array}{l}\text { Under Canadian federal law a bank is an entity that is incorporated and } \\
\text { regulated at the federal level. A bank, by definition, cannot exist at the } \\
\text { provincial level. Canadian federal law does not, however, apply to all financial } \\
\text { institutions that which may take deposits from the public. There are some } \\
\text { institutions which are systemically significant for their provinces, notably } \\
\text { Desjardins, the internationally active credit union group based in Québec, and } \\
\text { Alberta Treasury Branches, which is a Crown incorporation owned and regulated } \\
\text { by the province of Alberta. } \\
\text { The BCP assessment focuses on the federal level in Canada and does not offer } \\
\text { any assessment of the adequacy and appropriate laws, regulation and } \\
\text { supervision applying to provincial deposit taking entities. However, it is clear } \\
\text { that the scope of the federal system does not, and legally cannot, include all } \\
\text { deposit- taking entities of significance. }\end{array}$ \\
\hline 5. Licensing $c$ & $\begin{array}{l}\text { Entry into the Canadian banking system is carefully vetted. OSFI's risk tolerance } \\
\text { around new entrants is low and focused on prudential and national security } \\
\text { considerations as required by law. The criteria for licensing are established in } \\
\text { law and articulated in OSFI guidelines and implemented through rigorous and } \\
\text { well-executed policies and processes. } \\
\text { Licensing is a two-step process, sometimes called a "two key" process in } \\
\text { Canada. Although an applicant needs to obtain approval from both OSFI and } \\
\text { the Minister in order to carry out business as a bank, the Minister's approval is } \\
\text { not and cannot be sought unless OSFI has already made a favourable prudential } \\
\text { determination. Furthermore, the institution cannot commence business unless } \\
\text { and until OSFI is satisfied that all prudential standards are met and the }\end{array}$ \\
\hline
\end{tabular}




\begin{tabular}{|c|c|}
\hline & $\begin{array}{l}\text { Superintendent issues the order to commence business. } \\
\text { Standards established for licensing also apply for ongoing supervision except in } \\
\text { one regard. OSFI does not, after licensing, carry out a fit and proper assessment } \\
\text { of new directors and senior management on an ongoing basis. }\end{array}$ \\
\hline $\begin{array}{l}\text { 6. Transfer of significant } \\
\text { ownership }\end{array}$ & $\begin{array}{l}\text { Banks must submit an annual "Return of Shareholders" but this filing does not } \\
\text { always identify ultimate beneficial shareholders. } \\
\text { There is no specific requirement for banks to notify OSFI of material adverse } \\
\text { changes affecting the suitability of a major shareholder or controller. The risks } \\
\text { related to both these notification issues is managed in the context of the } \\
\text { supervisory relationship with the institution, and is, again, negligible in the } \\
\text { context of the widely held banks but not necessarily so for smaller institutions. } \\
\text { The issue of the "prudential veto" in respect of approvals granted by the } \\
\text { Minister is relevant to this principle. }\end{array}$ \\
\hline 7. Major acquisitions & $\begin{array}{l}\text { The Bank Act sets clear limits upon and requirements for Ministerial approval of } \\
\text { major acquisitions carried out by banks. Where an acquisition is subject to } \\
\text { Ministerial approval, the regime of acquisition and investment is implemented } \\
\text { through OSFI and the Minister. The preparation work for approval on prudential } \\
\text { grounds is performed by OSFI and a recommendation to the Minister for } \\
\text { approval is only put forward if OSFI is satisfied it is suitable to do so. In carrying } \\
\text { out its assessment OSFI considers all the requirements of prudential soundness, } \\
\text { including the future supervisability of the group following the acquisition. In } \\
\text { common with the ownership regime discussed in CP6, it is unclear that there is } \\
\text { a "prudential veto" securely in placeCP2.) } \\
\text { There is no approval required for acquisitions made through a foreign or } \\
\text { provincially regulated subsidiary. This is not required by the principle but } \\
\text { exposes OSFI and the bank itself to the risk that acquisitions are approved by } \\
\text { foreign regulator with differing standards or powers. }\end{array}$ \\
\hline 8. Supervisory approach & $\begin{array}{l}\text { OSFI has developed an excellent supervisory approach that supports the } \\
\text { analysis of risk from multiple perspectives, in particular that of identifying the } \\
\text { significant activities within the firm. The risk approach incorporates a forward } \\
\text { looking time dimension. In particular the OSFI approach marries its risk analysis } \\
\text { to a supervisory outcome that can be clearly communicated to the institution, } \\
\text { through the use of the intervention rating and the "stages" of supervisory } \\
\text { intensity should matters of concern emerge. }\end{array}$ \\
\hline $\begin{array}{l}\text { 9. Supervisory } \\
\text { techniques and tools }\end{array}$ & $\begin{array}{l}\text { OSFI has high standards of supervisory practice and a supervisory style and } \\
\text { structure that is oriented around a close touch principle that is consistently } \\
\text { delivered. This approach underpins OSFI's ability to articulate and reinforce its } \\
\text { supervisory expectations. OSFI is perceived as accessible to the industry and its } \\
\text { willingness to listen was widely praised. While OSFI's perceived lack of rigidity }\end{array}$ \\
\hline
\end{tabular}




\begin{tabular}{|c|c|}
\hline & $\begin{array}{l}\text { was appreciated, OSFI's authority with the firms was confirmed. } \\
\text { The close touch approach yields many benefits to OSFI in terms of supervisory } \\
\text { outcomes but the challenge that always remains is that close understanding of } \\
\text { the counterpart can lead to a loss of direction and momentum such that OSFI } \\
\text { must guard against being slow to be assertive. }\end{array}$ \\
\hline $\begin{array}{l}\text { 10. Supervisory } \\
\text { reporting }\end{array}$ & $\begin{array}{l}\text { OSFI receives standard prudential data from firms as well as much management } \\
\text { information and ad hoc data. Gaps in prudential data relate to large exposures } \\
\text { and related party lending and are reflected in CPs } 19 \text { and 20, respectively. OSFI } \\
\text { makes financial data on the banks publicly available on its website. } \\
\text { OSFI's emphasis on obtaining management information from firms is consistent } \\
\text { with the supervisory approach that focuses on significant activities carried out } \\
\text { by the firms. Necessarily, though, management information is less susceptible } \\
\text { to peer group analysis (between entity and over time) as it is not standardized } \\
\text { for purposes of comparison. } \\
\text { OSFI has established process for regular review of reporting requirements, and } \\
\text { should ensure that this process is keeping pace with needs. }\end{array}$ \\
\hline $\begin{array}{l}\text { 11. Corrective and } \\
\text { sanctioning powers of } \\
\text { supervisors }\end{array}$ & $\begin{array}{l}\text { OSFI has a wide range of corrective and sanctioning powers under the Bank Act. } \\
\text { OSFI's mandate requires early intervention and OSFI has designed, in } \\
\text { collaboration with the CDIC, a structured approach for applying progressively } \\
\text { more intensive supervisory intervention. The intervention approach is } \\
\text { predicated on OSFI's direct powers, although OSFI's preference is to obtain } \\
\text { traction with the firm on a voluntary basis, where OSFI's authority is } \\
\text { underpinned by the existence of its legal powers. OSFI carries out its } \\
\text { intervention carefully, with the understanding that it must build its legal case at } \\
\text { each stage in the event it has recourse to the use of its powers. } \\
\text { The "staging" process allows OSFI to intensify restrictions and requirements for } \\
\text { an institution (limitation on business, higher capital etc) and it exerts a discipline } \\
\text { on chief executives who must report to their boards that they have been staged. } \\
\text { While this particular discipline of transparency may be less effective in smaller } \\
\text { institutions, the financial consequences of restrictions, are likely to be felt. } \\
\text { An institution might remain "staged" for a period of time as remedial action and } \\
\text { OSFI's further review cannot always be a rapid process. The challenge for OSFI is } \\
\text { to maintain pressure on the institution to make meaningful progress over a } \\
\text { credible and situation-specific appropriate timeline in order to exit staging (and } \\
\text { not relapse in the near future). OSFI is conscious of this risk. }\end{array}$ \\
\hline $\begin{array}{l}\text { 12. Consolidated } \\
\text { supervision }\end{array}$ & $\begin{array}{l}\text { OSFI has a strong legal and regulatory framework for consolidated supervision } \\
\text { that it applies consistently. OSFI is mindful of the distribution of risks } \\
\text { throughout the group and the need for strong risk management, internal } \\
\text { controls and flow of information within the consolidated groups. }\end{array}$ \\
\hline
\end{tabular}




\begin{tabular}{|c|c|}
\hline & $\begin{array}{l}\text { OSFI goes beyond the Basel framework by requiring solo entity information on } \\
\text { the parent banks for the systemic banking groups in Canada but generally } \\
\text { places less emphasis on the individual banks within groups, structuring its work } \\
\text { around the concept of "significant activity". Recent work on recovery and } \\
\text { resolution planning though has required group structures to be scrutinized on } \\
\text { legal entity basis and, by OSFI's own admission has "shone a light" on issues } \\
\text { that may need to be assessed on a prudential basis. }\end{array}$ \\
\hline $\begin{array}{l}\text { 13. Home-host } \\
\text { relationships }\end{array}$ & $\begin{array}{l}\text { OSFI has a more significant role as a home supervisor than a host supervisor } \\
\text { and in some regions outside Canada, the major Canadian banks are systemic for } \\
\text { the local economy. OSFI monitors the evolution and development of its banks } \\
\text { in foreign territories and allocates supervisory resources accordingly. } \\
\text { Home and host relationships appear to be strong in relation to significant } \\
\text { overseas relationships and to function smoothly where Canadian banking } \\
\text { presence may be strong locally, but is relatively minor in respect of the group's } \\
\text { activities. OSFI has witnessed the growing confidence and effectiveness of its } \\
\text { collegiate relationships and is moving to target more specific themes. Work on } \\
\text { crisis management, resolution and recovery is progressing, in coordination with } \\
\text { the CDIC. }\end{array}$ \\
\hline $\begin{array}{l}\text { 14. Corporate } \\
\text { governance }\end{array}$ & $\begin{array}{l}\text { OSFI has a comprehensive program for supervision of corporate governance at } \\
\text { large and smaller banks. Notable features of the approach include very regular } \\
\text { contact with directors on both a formal and informal level, and a centralized } \\
\text { unit responsible for corporate governance supervision. }\end{array}$ \\
\hline $\begin{array}{l}\text { 15. Risk management } \\
\text { process }\end{array}$ & $\begin{array}{l}\text { OSFI's practical implementation of risk management supervision is of a very } \\
\text { high standard in terms of scope, depth and quality of analysis. Supervisors have } \\
\text { a rigorous process for assessing and rating inherent risk and the quality of risk } \\
\text { management and acting on any deficiencies. Specialist teams play an integral } \\
\text { part in providing risk-based review and peer comparison. } \\
\text { OSFI operates at a principles-based level and does not tend to issue extensive, } \\
\text { detailed risk management guidance. While this approach is more flexible and } \\
\text { potentially responsive to differing institutions and risks, OSFI could usefully } \\
\text { provide a more comprehensive and consistent set of written guidance as to its } \\
\text { expectations across all risk areas. The existing set of standards dealing with risk } \\
\text { management is characterized by somewhat inconsistent format and application } \\
\text { (guidelines vs. advisories), does not comprehensively cover all risk areas (credit } \\
\text { risk, operational risk, problem asset management, concentrations and country } \\
\text { risk) or limited in application (market risk). As a world-leading regulator it would } \\
\text { be expected that OSFI would make available to banks a comprehensive suite of } \\
\text { risk management standards, even if at a relatively high level or based largely on } \\
\text { BCBS guidance. }\end{array}$ \\
\hline 16. Capital adequacy & active and conservative approach to capital adequacy. \\
\hline
\end{tabular}




\begin{tabular}{|c|c|}
\hline & $\begin{array}{l}\text { Supervisors regularly assess banks' capital management and planning and use } \\
\text { stress testing to assess the adequacy of capital on a regular basis. } \\
\text { OSFI has fully adopted Basel II and Basel III and has accelerated the timeline for } \\
\text { banks to implement the fully phased-in requirements. This approach should } \\
\text { help maintain the reputation of Canadian banks as subject to a strong and } \\
\text { conservative capital regime. In addition, OSFI has retained its own leverage ratio } \\
\text { requirement in addition to the Basel risk-based ratios. } \\
\text { Canada has also been one of the first countries to establish its regime for } \\
\text { domestically systemically important banks (D-SIBs) consistent with the BCBS } \\
\text { standard and to announce that it will impose a } 1 \text { percent capital surcharge, } \\
\text { effective in } 2016 \text {. } \\
\text { Concerns regarding inconsistencies across countries in the internal modeling of } \\
\text { capital requirements by banks have emerged as an international concern. OSFI } \\
\text { has implemented a rigorous program to review and approve banks' internal } \\
\text { models. Some recent reviews of credit risk IRB modeling across banks in } \\
\text { particular lending segments have found deficiencies in complying with OSFI } \\
\text { expectations. This situation is not unusual for many countries, but calls into } \\
\text { question whether banks had sufficient clarity about OSFI's expectations. OSFI } \\
\text { has significant model validation work underway including follow-up with banks } \\
\text { on identified issues. Moreover, OSFI has been careful to communicate an overall } \\
\text { message to banks that there will be no capital reductions from modeling } \\
\text { without associated improvements in risk measurement and management. } \\
\text { However, continued vigilance will be required in this area. }\end{array}$ \\
\hline 17. & $\begin{array}{l}\text { OSFI's credit risk supervision function is effective and forward-looking. } \\
\text { Supervisors conduct regular detailed on-site review of banks' significant and } \\
\text { higher risk portfolios; any areas of emerging concern are investigated and } \\
\text { action taken on rectification. OSFI and banks make active use of stress testing to } \\
\text { evaluate the nature and size of risks in their portfolio. } \\
\text { While OSFI has issued guidance on specific credit risk areas such as residential } \\
\text { mortgages and valuations, as well as on capital requirements for credit risk, it } \\
\text { does not have an overarching credit risk management guideline. Most } \\
\text { regulators have issued broad supervisory guidance on credit risk management. }\end{array}$ \\
\hline $\begin{array}{l}\text { 18. Problem assets, } \\
\text { provisions, and reserves }\end{array}$ & $\begin{array}{l}\text { Supervisors review the appropriateness of loan classification and the speed of } \\
\text { recognition during on-site credit risk reviews. Credit quality indicators for the } \\
\text { industry and individual banks are closely monitored and reported to OSFI } \\
\text { management and supervisors. Levels of problem assets in most lending } \\
\text { segments remain low but attention to problem asset management processes is } \\
\text { critical to detect and manage any early negative trends. } \\
\text { Problem asset management appears to be well covered in on-site credit risk }\end{array}$ \\
\hline
\end{tabular}




\begin{tabular}{|c|c|}
\hline & reviews, but little published guidance is available from OSFI. \\
\hline $\begin{array}{l}\text { 19. Concentration risk } \\
\text { and large exposure } \\
\text { limits }\end{array}$ & $\begin{array}{l}\text { Although concentration risk management is mentioned at a high level in } \\
\text { guidance on stress testing and ICAAPs, in practice there was good evidence that } \\
\text { OSFI Supervisors monitor concentrations individual bank portfolios and take } \\
\text { action when concentrations appear excessive. Through its risk surveillance and } \\
\text { monitoring unit, the risk specialist teams and the Emerging Risk Committee, } \\
\text { OSFI has a strong capability for identifying and monitoring concentrations } \\
\text { across the industry and ensuring that attention is focused on them through } \\
\text { stress testing and cross-industry reviews. } \\
\text { OSFI imposes a } 25 \text { percent of capital limit on large exposures. Although OSFI } \\
\text { maintains a database of larger banks' exposures above } \$ 10 \text { million, there is no } \\
\text { formal regulatory return for large exposure limit compliance reporting to } \\
\text { supervisors covering all banks or a clear notification threshold for action or } \\
\text { closer monitoring. In addition, the limit for subsidiary banks is substantially } \\
\text { higher (100 percent of capital). }\end{array}$ \\
\hline $\begin{array}{l}\text { 20. Transactions with } \\
\text { related parties }\end{array}$ & $\begin{array}{l}\text { By law transactions with related parties are prohibited with certain key } \\
\text { exceptions. There are explicit board reporting and oversight requirements for } \\
\text { related party transactions set out in the Bank Act. OSFI supervisors typically } \\
\text { review a bank's oversight of compliance obligations, generally on an annual } \\
\text { basis. However, there is no formal regulatory return for reporting related party } \\
\text { exposures more frequently to OSFI. } \\
\text { In addition, the Bank Act limit on aggregate related party exposures to directors } \\
\text { and officers of } 50 \text { percent of capital is very high relative to the limits on large } \\
\text { exposures and international expectations. }\end{array}$ \\
\hline $\begin{array}{l}\text { 21. Country and transfer } \\
\text { risks }\end{array}$ & $\begin{array}{l}\text { OSFI supervisors monitor and ensure appropriate management of key country } \\
\text { exposures of concern (for example, Eurozone, U.S. and Caribbean loan books). } \\
\text { Supervisors of the large banks regularly obtain reports on banks' largest foreign } \\
\text { exposure concentrations. } \\
\text { Although country risk management is covered under other guidance at a high } \\
\text { level, OSFI has not issued specific guidance on the management of country and } \\
\text { transfer risks that clarify and detail OSFI's expectations. }\end{array}$ \\
\hline 22. Market risk & $\begin{array}{l}\text { OSFI's market risk supervision program for large banks appears comprehensive } \\
\text { and includes both on-site review of practices as well as detailed model review. }\end{array}$ \\
\hline $\begin{array}{l}\text { 23. Interest rate risk in } \\
\text { the banking book }\end{array}$ & $\begin{array}{l}\text { OSFI has issued guidance on interest rate risk management and banks are } \\
\text { expected to reflect interest rate risk in their ICAAPs. Supervisors conduct regular } \\
\text { off-site monitoring through standard reporting of interest rate shock impacts } \\
\text { on earnings and capital. A proactive approach to interest risk management will, } \\
\text { of course, be critical in a rising interest rate risk environment. }\end{array}$ \\
\hline
\end{tabular}




\begin{tabular}{|c|c|}
\hline 24. Liquidity risk & $\begin{array}{l}\text { OSFI has applied a strong focus on liquidity management since the financial } \\
\text { crisis and has maintained this intensity. Banks have significantly increased their } \\
\text { liquidity reserves and adopted more prudent funding profiles, relative to the } \\
\text { start of the crisis. OSFI developed its own liquidity measure and has } \\
\text { progressively raised the expectations on banks for maintaining a prudent level } \\
\text { of liquid assets, moving toward compliance with the new Basel III measures as } \\
\text { soon as possible and reducing reliance on short-term wholesale funding. } \\
\text { Much of OSFI's recent liquidity supervision for the large banks has been } \\
\text { conducted through off-site monitoring. }\end{array}$ \\
\hline 25. Oper & $\begin{array}{l}\text { OSFI has a strong program for assessing operational risk management at banks. } \\
\text { OSFI employs a dedicated operational risk team, which includes technology risk } \\
\text { experts. It reviews banks' operational risk framework with a view to promoting } \\
\text { best practice, and conducts regular cross-industry reviews to highlight areas of } \\
\text { potential concern, such as legacy systems and cyber risks. OSFI has relied } \\
\text { explicitly on the BCBS Sound Practice guidance in setting expectations for } \\
\text { banks, but has not issued its own overall guidance on operational risk. OSFI has } \\
\text { issued guidance in targeted areas such as outsourcing. }\end{array}$ \\
\hline $\begin{array}{l}\text { 26. Internal control and } \\
\text { audit }\end{array}$ & $\begin{array}{l}\text { OSFI's supervision program includes a high degree of interaction with the } \\
\text { internal audit functions of banks and their reporting to the bank's audit } \\
\text { committee. Supervisors appear to have appropriately balanced oversight and } \\
\text { use of internal audit work auditors without placing undue reliance on it. }\end{array}$ \\
\hline $\begin{array}{l}\text { 27. Financial reporting } \\
\text { and external audit }\end{array}$ & $\begin{array}{l}\text { OSFI supervisors have established strong ongoing communication channels } \\
\text { with external auditors and are able to leverage their resources and expertise } \\
\text { when needed.While auditors have a statutory duty to report to the bank and } \\
\text { OSFI issues affecting the well being of the bank, the 'well being letter' } \\
\text { requirements may not cover all matters of prudential interest to OSFI. In } \\
\text { addition, the formal statutory nature of this requirement may hinder timely and } \\
\text { open communication of matters of potential prudential concern. OSFI expects } \\
\text { to require banks to adhere to the new BCBS guidance on external audit, which } \\
\text { will include a more generalised reporting requirement on matters of prudential } \\
\text { concern. }\end{array}$ \\
\hline $\begin{array}{l}\text { 28. Disclosure and } \\
\text { transparency }\end{array}$ & $\begin{array}{l}\text { OSFI has implemented all Pillar } 3 \text { requirements and has been proactive in } \\
\text { including enhanced disclosure expectations for Canadian banks. Canadian D- } \\
\text { SIBs will be expected to adopt the recommendations of the Financial Stability } \\
\text { Board's Enhanced Disclosure Task. } \\
\text { Pillar } 3 \text { requirements have been issued in Advisories rather than a Guideline. } \\
\text { Advisories provide OSFI with greater flexibility particularly for technical or policy } \\
\text { matters subject to change. } \\
\text { In keeping with OSFI's leading practice in other areas, OSFI could provide } \\
\text { greater financial and risk data in a more useable format for analysis by the }\end{array}$ \\
\hline
\end{tabular}




\begin{tabular}{|l|l|}
\hline & $\begin{array}{l}\text { public. The OSFI data access tool on its web site is not particularly user friendly, } \\
\text { does not facilitate analysis (for example, over time or across peers) or flexible } \\
\text { access (for example, via spreadsheet). Some other regulators publish } \\
\text { substantially more information in time series format on bank performance and } \\
\text { risk indicators at the aggregate and individual institution level. }\end{array}$ \\
\hline $\begin{array}{l}\text { 29. Abuse of financial } \\
\text { services }\end{array}$ & $\begin{array}{l}\text { The last FATF review identified concerns in relation to FINTRAC's supervisory } \\
\text { practices and the lack of enforceable customer due diligence requirements in } \\
\text { the PCMLTFA. In terms of the assessment under the Basel Core Principles and } \\
\text { the specific formulation of the criteria, the test is not identical, however minor } \\
\text { deficiencies remain including areas in which greater clarity or focus are } \\
\text { desirable. }\end{array}$ \\
\hline
\end{tabular}

\section{E. Recommendations}

\begin{tabular}{|c|l|}
\hline \multicolumn{2}{|c|}{ Table 2. Recommendations to Improve Observance of the BCPs } \\
\hline \multicolumn{1}{|c|}{ Reference Principle } & \multicolumn{1}{c|}{ Recommended Action } \\
\hline $\begin{array}{l}\text { 1. Responsibilities, } \\
\text { objectives and powers }\end{array}$ & $\begin{array}{l}\text { It is recommended that ways be explored to strengthen the enforceability of } \\
\text { guidelines through statutory changes to the powers of OSFI under the Bank Act. It } \\
\text { is further recommended that consideration be given to whether there are any key } \\
\text { prudential standards that would benefit from a migration to the format of a } \\
\text { regulation. }\end{array}$ \\
\hline $\begin{array}{l}\text { 2. Independence, } \\
\text { accountability, } \\
\text { protection for } \\
\text { supervisors }\end{array}$ & $\begin{array}{l}\text { It is recommended that the authorities codify the "prudential veto" clearly in the } \\
\text { Bank Act in respect of all approvals in which prudential considerations are relevant } \\
\text { (for example, transfer of ownership and investment). } \\
\text { It is recommended that the authorities consider exempting the supervisors from } \\
\text { the government's fiscal controls and administrative guidance, as in the case of } \\
\text { some other financial agencies, in order to enhance OSFI's financial autonomy. }\end{array}$ \\
\hline $\begin{array}{l}\text { 3. Cooperation and } \\
\text { collaboration }\end{array}$ & $\begin{array}{l}\text { It is recommended that more frequent and structured arrangements, modeled } \\
\text { perhaps on current formats, are put in place to ensure that relevant information is } \\
\text { shared actively and proactively as necessary between provincial and federal } \\
\text { authorities, rather than only on request, in order to enhance firm- and group- } \\
\text { specific supervision and wider systemic understanding. }\end{array}$ \\
\hline 4. Permissible activities & $\begin{array}{l}\text { The scope of the federal system does not, and cannot under current law, } \\
\text { encompass all deposit-taking entities of significance. The relevant Canadian } \\
\text { authorities should assess and as necessary revise laws and arrangements to ensure } \\
\text { the soundness and stability of the entire financial system within Canada, and not } \\
\text { only the federal aspect of that system. }\end{array}$ \\
\hline
\end{tabular}




\begin{tabular}{|c|c|}
\hline 5. Licensing criteria & $\begin{array}{l}\text { OSFI should institute a policy of assessing the fitness and properness of all new } \\
\text { board members and new senior management executives. }\end{array}$ \\
\hline $\begin{array}{l}\text { 6. Transfer of significant } \\
\text { ownership }\end{array}$ & $\begin{array}{l}\text { OSFI should consider a standardized form for the annual reporting of } \\
\text { shareholdings and should institute an annual check on ultimate beneficial } \\
\text { ownership on all institutions in order to obtain comfort that OSFI will have timely } \\
\text { notification should indirect holdings or changes in ownership and control- } \\
\text { whether increasing or decreasing - take place. } \\
\text { There should be a specific requirement for banks to notify OSFI of material adverse } \\
\text { changes affecting the suitability of a major shareholder or controller. It is } \\
\text { recommended that at a minimum OSFI introduce an explicit reporting } \\
\text { requirement. If necessary, a requirement to file such a report to the } \\
\text { Superintendent could be included in the next revision of the Bank Act. }\end{array}$ \\
\hline 7. Major acquisitions & $\begin{array}{l}\text { It is recommended that the Bank Act be amended to introduce an approval, or at } \\
\text { minimum, notification requirement to OSFI when an acquisition is made through a } \\
\text { foreign or provincially-regulated subsidiary. }\end{array}$ \\
\hline 8. Supervisory approach & $\begin{array}{l}\text { It is recommended that OSFI intensify its analysis of groups from a legal entity } \\
\text { based perspective to complement the understanding yielded by the examination } \\
\text { of significant activities. OSFI should also review the effectiveness of its } \\
\text { communication and coordination with non-bank regulators for entities within the } \\
\text { consolidated groups. }\end{array}$ \\
\hline $\begin{array}{l}\text { 9. Supervisory techniques } \\
\text { and tools }\end{array}$ & $\begin{array}{l}\text { It is recommended that OSFI consider whether its internal monitoring systems } \\
\text { could be enhanced to further support the overarching, and risk-focused view of } \\
\text { the institution to ensure timely actions and progress. } \\
\text { A requirement should be introduced, through amendment to the Bank Act or } \\
\text { otherwise, for a bank to notify OSFI in advance of any material adverse } \\
\text { development in the institution. }\end{array}$ \\
\hline 10. Supervisory reporting & $\begin{array}{l}\text { It is recommended that OSFI review its prudential data needs to support ongoing } \\
\text { supervision, taking into account particularly recent work on recovery and } \\
\text { resolution planning which places greater focus on the individual legal entities. }\end{array}$ \\
\hline $\begin{array}{l}\text { 11. Corrective and } \\
\text { sanctioning powers of } \\
\text { supervisors }\end{array}$ & $\begin{array}{l}\text { It is recommended that OSFI institute post facto reviews of staging cases in } \\
\text { addition to interim reviews in order to identify how best to ensure appropriate } \\
\text { momentum through the staging phase. } \\
\text { The authorities should consider whether further legal authority or powers are } \\
\text { required to enable them to move more promptly to address situations where a } \\
\text { bank's business model is deemed or proved to be non-viable over a period of } \\
\text { time. }\end{array}$ \\
\hline $\begin{array}{l}\text { 12. Consolidated } \\
\text { supervision }\end{array}$ & $\begin{array}{l}\text { OFSI should require solo data for all regulated banks within the consolidated } \\
\text { banking groups where this is not already the practice. }\end{array}$ \\
\hline
\end{tabular}




\begin{tabular}{|c|c|}
\hline & $\begin{array}{l}\text { It is recommended that OSFI require periodic data on intra-group transactions. } \\
\text { OSFI should formalize its policy to always make access to parental data and } \\
\text { notification of material parental business and governance changes a condition of } \\
\text { licensing for those instances where the parent entity is not a regulated entity. }\end{array}$ \\
\hline $\begin{array}{l}\text { 13. Home-host } \\
\text { relationships }\end{array}$ & $\begin{array}{l}\text { It is recommended that in its recovery planning, OSFI consider and anticipate the } \\
\text { potential needs in a crisis of supervisors in jurisdictions where the Canadian entity } \\
\text { is material. }\end{array}$ \\
\hline $\begin{array}{l}\text { 15. Risk management } \\
\text { process }\end{array}$ & $\begin{array}{l}\text { OSFI should review its current set of prudential Guidelines relating to risk } \\
\text { management against international standards and other OSFI prudential } \\
\text { expectations and issue expanded or new guidance to close any identified gaps, } \\
\text { particularly in areas such as credit risk. }\end{array}$ \\
\hline 16. Capital adequacy & $\begin{array}{l}\text { Over time, OSFI may wish to consider whether the D-SIB capital surcharge should } \\
\text { differ across banks according to their risk or systemic importance. It is } \\
\text { recommended that OSFI seek a formal BCBS Basel III FAQ to be published } \\
\text { regarding the 'purchase for cancellation' provision for Additional Tier } 1 \text { and Tier } 2 \\
\text { capital instruments. }\end{array}$ \\
\hline 17. Credit risk & $\begin{array}{l}\text { As discussed under BCP 15, OSFI should develop comprehensive guidance on } \\
\text { credit risk management in line with international standards to ensure its } \\
\text { expectations and minimum standards are well understood. }\end{array}$ \\
\hline $\begin{array}{l}\text { 18. Problem assets, } \\
\text { provisions, and reserves }\end{array}$ & $\begin{array}{l}\text { OSFI should consider setting out its expectations with respect to problem asset } \\
\text { management in comprehensive guidance on credit risk management, as discussed } \\
\text { in BCP } 15 \text { and BCP } 17 \text {. }\end{array}$ \\
\hline $\begin{array}{l}\text { 19. Concentration risk and } \\
\text { large exposure limits }\end{array}$ & $\begin{array}{l}\text { It is recommended that OSFI strengthen its large exposure reporting and } \\
\text { monitoring regime to include, for example, regular regulatory reporting of } \\
\text { compliance and notification of exposures greater than a specified level of capital. } \\
\text { OSFI's Large Exposure Guideline dates from } 1994 \text { and OSFI should consider } \\
\text { updating its guidance in light of the BCBS project currently underway and to cover } \\
\text { concentration risks more generally. OSFI should also reconsider whether the } \\
\text { higher exposure limit for subsidiary banks continues to be appropriate. }\end{array}$ \\
\hline $\begin{array}{l}\text { 20. Transactions with } \\
\text { related parties }\end{array}$ & $\begin{array}{l}\text { OSFI should establish a more formalized regime, including regular regulatory } \\
\text { reporting, for monitoring related-party transactions. In addition, OSFI should } \\
\text { consider whether the Bank Act limit on aggregate related party exposures of } 50 \\
\text { percent of capital to directors and officers should be lowered to a level more } \\
\text { consistent with the limits on large exposures. }\end{array}$ \\
\hline $\begin{array}{l}\text { 21. Country and transfer } \\
\text { risks }\end{array}$ & $\begin{array}{l}\text { OSFI should consider issuing guidance documenting its expectations for the } \\
\text { management of country and transfer risks. }\end{array}$ \\
\hline 22. Market risk & $\begin{array}{l}\text { OSFI should consider clarifying its market risk management expectations for } \\
\text { foreign bank branches and banks with small or no trading books, which are not }\end{array}$ \\
\hline
\end{tabular}




\begin{tabular}{|l|l|}
\hline 24. Liquidity risk & subject to the Capital Adequacy Requirement Guideline on Market Risk. \\
\hline $\begin{array}{l}\text { OSFI should ensure that, even with significant off-site analysis, reporting and } \\
\text { review occurring, supervisors maintain regular on-site coverage of liquidity risk } \\
\text { management to verify the effective application of policies and controls in practice. }\end{array}$ \\
$\begin{array}{l}\text { 28. Disclosure and } \\
\text { transparency } \\
\text { OSFI should consider issuing more comprehensive guidance on setting out its } \\
\text { continuity expectations. }\end{array}$ \\
$\begin{array}{l}\text { As OSFI and the banks view Pillar 3 requirements as minimum required disclosure } \\
\text { practice, OSFI should consider issuing Pillar 3 requirements in Guideline format. } \\
\text { OSFI may wish to review best practices in other countries and consider publication } \\
\text { of time series data sourced from its regulatory returns that would enhance the } \\
\text { public understanding of banks' operations and risk profile. }\end{array}$ \\
\hline $\begin{array}{l}\text { 29. Abuse of financial } \\
\text { services }\end{array}$ & $\begin{array}{l}\text { It is recommended that OSFI explicitly state its expectation that banks' compliance } \\
\text { officer (CAMLO) is appointed at the management level. } \\
\text { It is also recommended that Guideline (B-10) on Outsourcing of Business Activities, } \\
\text { Functions and Processes be amended to more clearly establish the requirement } \\
\text { that the screening processes that are in place when the bank is entering into } \\
\text { outsourcing relationships will ensure high ethical and professional standards. }\end{array}$ \\
\hline
\end{tabular}

\section{F. Authorities' Response}

\section{The Canadian authorities wish to express their appreciation to the IMF and its} assessment team for their assessment of the Canadian banking sector. The Canadian authorities share the view that Canada, primarily through the Office of the Superintendent of Financial Institutions (OSFI), has a very high level of observance with the Basel Core Principles for Effective Banking Supervision (BCPs).

\section{Canada is highly committed to the FSAP process and the insights that the IMF can} provide with respect to a country's financial sector through this process. Canada fully agrees that it is important to continually review and seek to improve the regulatory framework and supervision practices.

\section{The IMF has made a number of observations and recommendations, which could} further enhance the very high degree of compliance with the BCPs. These will be given consideration by the relevant Canadian authorities, having due regard to the various initiatives currently planned or underway, and taking into account the features of the Canadian regime that contributed to the performance of the Canadian banking system during and post-crisis. 


\section{ASSESSMENT OF INSURANCE CORE PRINCIPLES}

\section{A. Summary}

19. The Canadian regulatory regime for insurance has a high level of observance with the Insurance Core Principles (ICPs). OSFI's risk-based Supervisory Framework facilitates structured and comprehensive supervisory risk assessments and the industry has a high regard for the professionalism of OSFI supervisors. OSFI has a generally robust set of financial requirements, including comprehensive requirements on valuation of technical provisions and assets, professional and regulatory requirements applying to the appointed actuary and capital adequacy frameworks, separate for Life and Health ( $L \& H)$ and Property and Casualty $(P \& C)$ business, that capture all material risks. A distinguishing feature and a strength of OFSI's regime is its application on a consolidated basis to each operating Federally-Regulated Insurance company (FRI).

20. There are also a generally sound conduct of business (COB) regimes across provinces. The COB regime adopted by the Authorité des marchés financiers (AMF) in Québec is in line with international best practice and it has adequate resources to conduct effective risk-based $C O B$ supervision. Constrained by limited resources, the Financial Services Commission of Ontario (FSCO) has adopted both a reactive and industry-wide targeted approach to supervising the FRIs based in Ontario (the vast majority of the total) and large numbers of insurance intermediaries.

\section{There is scope for strengthening the legal capacity and operational autonomy of the} supervisors as well as prudential and COB standards and the supervision of insurance groups. The authorities should consider empowering supervisors to issue enforceable rules by administrative means. Laws applying to OSFI and the AMF should be updated to separate provisions governing prudential decisions of supervisors from national interest issues. Laws applying to FSCO should be amended to limit the circumstances under which the provincial government can issue it a policy statement. It is recommended that the authorities adopt a transparent and consistent regulatory regime for group-wide supervision. OSFI should be empowered to take supervisory measures at the level of the holding company. OSFI should develop and apply a full framework of capital and disclosure requirements to all Canadian solo legal entity FRIs within groups. The provincial authorities should continue to harmonize their $\mathrm{COB}$ regimes, while ensuring adequate supervisory resources for effective $\mathrm{COB}$ supervision. FSCO should be equipped with adequate resources and financial capacity to deal with the size and diversity of the Ontario marketplace.

\section{B. Introduction and Scope}

\section{Canada's regulatory regime and supervisory practices were assessed ${ }^{2}$ against the} standards established by the International Association of Insurance Supervisors (IAIS). The assessment was undertaken against the IAIS Insurance Core Principles (ICPs) issued in October 2011,

\footnotetext{
${ }^{2}$ The assessment team comprised Su Hoong Chang (IMF) and Ian Tower (ex-IMF, Consultant).
} 
as revised in October 2012. The ICPs apply to all insurers, whether private or government-controlled. Specific principles apply to the supervision of intermediaries. The scope of the assessment covered:

a) the prudential supervision exercised by the OSFI at the federal level based on materiality considerations ${ }^{3}$ i.e. prudential oversight of insurers by provincial authorities is not covered; and b) the COB regimes of the Financial Services Commission of Ontario (FSCO) and the Autorité des marchés financiers (AMF) in Québec, on a sampling basis.

\section{The assessment is based solely on the laws, regulations and other supervisory} requirements and practices that are in place at the time of the assessment in June 2013. The authorities have provided a full and well-written self-assessment, supported by anonymized examples of actual supervisory practices and assessments, which enhanced the robustness of the assessment. Technical discussions with and briefings by officials from OSFI, FSCO and AMF also enriched this report; as did discussions with industry participants.

\section{Market and Institutional Setting}

\section{Insurance penetration and density ${ }^{4}$ for the Canadian L\&H industry is in line with other} advanced markets, although lower in the case of P\&C insurance. $\mathrm{L} \& \mathrm{H}$ insurance penetration is 3.2 percent and insurance density Can $\$ 1,687$, comparable to the average penetration and density for advanced markets of 3.6 percent and US $\$ 1,543$ as at end-2011. The penetration and density ratios of the $P \& C$ industry as at end-2012 were 2.37 percent and Can $\$ 1,234$, respectively, significantly lower than the average ratios for advanced markets of 5.0 percent and US\$2,168, respectively, as at end-2011. ${ }^{5}$ Reinsurance penetration and density is low at 0.63 percent and Can $\$ 330$, respectively, in 2012. The number of domestic employees in the insurance industry is approximately 254,400 at end-2011.

\section{The number of FRIs has been consolidating while there is a shift in the composition of} provincial insurers. As at end-2012, there were 264 FRIs, down from 290 in 2008, with P\&C FRIs accounting for 57 percent of FRIs. The P\&C industry is much smaller than the L\&H industry and accounted for 17 percent of total industry assets in 2012. In addition, 80 foreign insurers had been licensed to operate as branches in Canada. There are 23 captive insurers, all based in British Columbia. Although the number of provincial insurers is comparable to FRIs, assets held by provincial insurers (Can $\$ 75.4$ billion) represent about 11 percent of the assets held by FRIs as at end2011. Provincial insurers in Québec had the largest provincial asset base at more than Can $\$ 60$ billion. $^{6}$

\footnotetext{
${ }^{3}$ Currently, the vast majority of Canadian insurers are incorporated at the federal level. Insurers that incorporate in a specific province are subject to the solvency oversight of that province.

${ }^{4}$ Insurance penetration is premiums as a percentage of GDP while insurance density is premium per capita.

${ }^{5}$ Source: World Insurance in 2011, Swiss Re (data on advanced markets).

${ }^{6}$ Source: CCIR Report on provincially chartered insurers and provincial solvency supervision frameworks, March 2013.
} 
26. The L\&H industry is dominated by three large internationally active insurance groups with significant operations in the U.S., Asia and Europe. Together, Manulife Financial Corporation (MFC), Sun Life Financial Inc. (SLF) and The Great West Life Assurance Company (GWL) held just under 76 percent of total life insurance assets in Canada in 2012, at the legal entity level. In recent years, SLF and MFC have retrenched their U.S. operations significantly, particularly in the variable annuities business. The largest foreign market for the top three insurance groups is the U.S. While assets held in respect of their Asian operations were relatively low, Asia is viewed as a potential growth market, representing 19 percent of premiums written in 2012.

\section{The $\mathbf{P \& C}$ industry is less concentrated than the L\&H industry, with foreign-owned insurers having significant market share. It comprises local subsidiaries of the large global} groups, subsidiaries of the large Canadian banks as well as mutual/co-operative organizations. The top-10 P\&C FRIs produced 46 percent of total industry premium in 2012. Branches or subsidiaries of large global reinsurance groups dominate the reinsurance sector. Assets held by reinsurers totaled only Can $\$ 29$ billion or 3 percent of the assets of direct insurers.

28. The insurance sector is adequately served by a wide range of intermediaries. As at end2012, there were approximately 154,000 insurance agents (or approximately one for every 225 Canadians) and 45,000 insurance brokers. Brokers have diverse business models comprising: a large number of small, often family-owned, "main street" brokers; larger regional brokers; and the largest international brokerage groups. In recent years, managing general agencies ${ }^{7}$ (MGAs) have gained almost half the market share for L\&H distribution channel.

29. The investment portfolios of L\&H FRIs are diversified, with moderate exposure to real estate. Allocation to fixed income securities has been consistently above 65 percent of investment portfolios (excluding the segregated funds) in the last five years. Excluding the segregated funds, FRIs' investments in real estate (directly and through mortgage loans) accounted for 20 percent of their assets as at end-2012. L\&H FRIs also invested in alternative asset classes, e.g. some Can $\$ 20$ billion was invested in private placement debts. The L\&H insurance groups wrote more than half of their segregated fund portfolios outside of Canada, with assets totaling Can $\$ 422$ billion at the consolidated level as at end-2012.

30. The investment profile of the P\&C industry is conservative, heavily weighted in fixed income securities. Government and corporate bonds constituted more than 85 percent of the investments of P\&C FRIs for the last five years. In addition, almost the entire debt security portfolio was invested in Canadian debt securities. They have negligible exposures to the real estate sector. While L\&H FRIs have negligible off-balance sheet activities, some P\&C FRIs are active in securities lending. Canadian P\&C FRIs have not participated in insurance linked securities (ILS). However, some parent entities have participated in the ILS market for Canadian perils but the Canadian FRIs are not taking credit on the balance sheet for these ILS.

\footnotetext{
${ }^{7}$ In the late 1990's, many major life insurers began to dismantle their career agency distribution model through their branch networks in favor of contractual arrangements with life brokerage firms, which became known as MGAs.
} 
31. L\&H FRIs have been increasing their technical provisions, despite the steady decline in premium revenue while the technical provisions for P\&C FRIs remain stable. The increase in L\&H technical provisions reflects the impact of the adoption of IFRS in 2011 of a rapid decline in fixed income yields. Non-participating policies ${ }^{8}$ account for the bulk of the technical provisions for traditional policies. The amounts reported under segregated fund policies reflect the assets deposited in the segregated funds, while some Can $\$ 10$ billion in provisions for the embedded guarantees are included as technical provisions for non-participating policies. New product initiatives for the last five years have featured price increases and the removal or weakening of guarantees. Product re-designs have resulted in a transfer of investment risks from insurers to policyholders. In the absence of growth, profitability of L\&H FRIs has been declining

32. The P\&C industry writes almost exclusively domestic risks; with motor insurance as the dominant line of business. Ontario automobile insurance is the single largest P\&C product, accounting for about 25 percent of the premiums of the $P \& C$ industry. While operating results have been favorable, declining investment returns has motivated a refocus on underwriting discipline. In addition, extreme weather and natural catastrophes had dampened results as the industry experienced its third straight year of catastrophe-related insurance claims above Can $\$ 1$ billion.

\section{The state-owned Canada Mortgage and Housing Corporation (CMHC) ${ }^{9}$ is currently one} of the largest FIs in Canada. In Canada, federally regulated lenders are required to insure residential mortgage loans with loan-to-value (LTV) ratio of greater than 80 percent against default by either the $\mathrm{CMHC}$ or by a private mortgage insurer. The mortgage insurance market is dominated by $\mathrm{CMHC}$ (about 70 percent market share) and Genworth Financial Mortgage Insurance Company Canada (25 percent). The federal government guarantees 90 percent of a private insurer's residential mortgage loans in the event of insolvency. The National Housing Act establishes authorities for OSFI to examine and report on CMHC's commercial operations to determine whether CMHC is carrying on its activities in a safe and sound manner and to access CMHC's books and records. As CMHC is a Crown corporation, OSFI does not have legal authorities to take enforcement actions in the case of $\mathrm{CMHC}$. OSFI is required to report the results of its examinations, including any recommendations, to the $\mathrm{CMHC}^{\prime}$ s responsible Minister, the Minister of Finance and CMHC's board of directors at least once per year.

34. The solvency position of L\&H industry has been eroded since $\mathbf{2 0 1 0}$ while the overall solvency of $\mathbf{P \& C}$ industry has remained stable. The solvency regimes applicable to $L \& H$ and $P \& C$ FRIs are different, including the solvency control levels. All L\&H and P\&C FRIs meet the minimum ratios of 120 percent and 100 percent, respectively. OSFI's has set a supervisory target of 150 percent for both classes of FRIs.

\footnotetext{
${ }^{8}$ Policies are those that entitle the policyholders to share in the profits of an insurer by way of policy dividends, which are declared at the discretion of the insurer in line with policyholders' reasonable expectations.

${ }^{9} \mathrm{CMHC}$ is a federal Crown corporation, incorporated under the Canada Mortgage and Housing Corporation Act (CMHC Act), and is accountable to Parliament through the Minister responsible for CMHC.
} 
35. L\&H FRIs are exposed to protracted low interest rates, volatile equity markets and slow economic growth, while P\&C FRIs confront difficult investment market conditions and significant natural catastrophe exposures. Given the long term nature of L\&H liabilities, FRIs who did not have adequate asset-liability management are vulnerable to the reinvestment risks arising from their legacy portfolios. Wealth management products are seen as a growth area as insurers shift investment risks to policyholders, with more focus on fee-based income. For P\&C insurers, the 2012 OSFI standardized stress test on earthquake identified insured losses of up to $\$ 32$ billion depending on the scenario. Mortgage insurers are exposed to potential tail events that are inherently correlated to the housing market and macro-economic risks.

36. Federal and provincial supervisors share responsibilities for supervising the insurance sector. OSFI is responsible for prudential supervision of insurers incorporated under the federal Insurance Companies Act (ICA). Insurers that are incorporated in a specific province are subject to the solvency oversight of that province. While some provinces, especially those with a significant mass of provincial insurers (e.g. Québec) have chosen to retain their autonomy in prudential supervision, a number of provinces ${ }^{10}$ are considering other options. OSFI also regulates the solvency and soundness of licensed Canadian branches of foreign insurers. The relevant provincial supervisors supervise the market conduct of all insurers (including FRIs) operating within their provinces. In some provinces, SROs are given delegated powers to supervise certain categories of intermediaries. OSFI and provincial regulators work closely with the Financial Transactions and Reports Analysis Centre of Canada (FINTRAC), which is responsible for ensuring compliance with Canada's Proceeds of Crime (Money Laundering) and Terrorist Financing Act.

\section{This assessment does not cover the Financial Consumer Agency of Canada (FCAC) in} view of its limited role in supervising the insurance sector. FCAC is an agency of the federal government established by Parliament in 2001 to consolidate and strengthen oversight of consumer protection measures in FRFIs, and to expand consumer education. FCAC focuses on the lending activities of FRFIs and administers the consumer provisions under the ICA.

\section{Coordination amongst provincial supervisors is facilitated by the Canadian Council of} Insurance Regulators (CCIR). The CCIR is a long-established inter-jurisdictional association of insurance regulators (i.e. federal, provincial and territorial authorities) with the mandate to promote an efficient and effective insurance regulatory system in Canada. OSFI participates in the meetings of the CCIR as an observer.

39. Canada has a well-established framework for setting actuarial standards. The Actuarial Standards Board issues technical standards (Standards of Practice). The Canadian Institute of Actuaries (CIA) issues and enforces professional and ethical standards for its members. Only Fellows of the CIA who meet the additional requirements in OSFI guidelines are qualified to sign actuarial

\footnotetext{
${ }^{10}$ For example, FSCO has proposed to cease providing for the provincial incorporation of new insurers.
} 
reports required by OSFI. The CIA is a self-regulatory professional body that is not subject to oversight. Disciplinary actions taken are published on the CIA's website.

\section{There is a variety of mechanisms for consumer protection in addition to COB} regulation undertaken by provincial authorities. There are national services for adjudicating on complaints against insurance companies (General Insurance OmbudService and the OmbudService for L\&H insurance). There are also provincial mechanisms. Policyholder compensation schemes cover all relevant policyholders of companies incorporated federally or by a provincial authority. For $\mathrm{L \& H}$ insurance, the private not for profit body Assuris provides compensation in case of failure (defined as the issuance of a winding-up order). In the P\&C sector, membership of the compensation body Property and Casualty Insurance Compensation Corporation (PACICC) is required by provincial supervisory authorities rather than by OSFI as a condition of licensing.

\section{Key Findings}

41. The Canadian regulatory regime for insurance has a high level of observance with the Insurance Core Principles (ICPs). OSFI's risk-based Supervisory Framework facilitates structured and comprehensive supervisory risk assessments and the industry has a high regard for the professionalism of OSFI supervisors. The supervisory intervention process is transparent and supports timely intervention to address emerging concerns. OSFI has adequate supervisory resources and technical capacity to conduct effective supervision. Minor gaps in the regulatory regime have been addressed by OSFI through its guidelines and supervision.

42. OSFI has a generally robust set of financial requirements. There are comprehensive requirements on valuation of technical provisions and assets, including a consistent economic basis for valuation across the balance sheet and margins for adverse deviation. The approach is underpinned by professional and regulatory requirements applying to the appointed actuary and a sound framework of oversight, peer review and audit requirements. The approach has been adapted where areas of weakness were highlighted by the financial crisis and OSFI's supervisory work. Separate capital adequacy frameworks apply to Life and Health (L\&H) and Property and Casualty (P\&C) business, capturing all material risks. OSFI allows firms to use internal models in limited areas, but applies a full model approval process and ongoing monitoring. A distinguishing feature and a strength of OFSI's regime is its application on a consolidated basis to each operating FRI.

43. Conduct of business (COB) regimes across provinces are being harmonized. The $C O B$ regime adopted by the Authorité des marchés financiers (AMF) in Québec is in line with international best practice and it has adequate resources to conduct effective risk-based COB supervision. Constrained by limited resources, the Financial Services Commission of Ontario (FSCO) has adopted both a reactive and industry-wide targeted approach to supervising the FRIs based in Ontario (the vast majority of the total) and large numbers of insurance intermediaries.

44. There is scope for strengthening the legal capacity and operational autonomy of the supervisors. OSFI's use of guidelines to set detailed standards confers flexibility. Nonetheless, the authorities should consider the scope to strengthen regulation by empowering the supervisors to 
issue enforceable rules by administrative means. In the case of OSFI and AMF, laws should be updated to separate provisions governing prudential decisions of supervisors from the national interest issues which the executive authorities must take into consideration; and in the case of FSCO, to limit the circumstances under which the provincial government can issue it a policy statement.

\section{Some changes in prudential and $\mathrm{COB}$ standards and the supervision of insurance} groups are required. It is recommended that the authorities adopt a transparent and consistent regulatory regime for group-wide supervision, based on a clear definition of the group, which includes prudential and market conduct requirements at the group level as well as a consistent approach to the application of group capital requirements and group-wide supervisory work. It is advisable that OSFI be empowered to take supervisory measures at the level of the holding company. OSFI should develop and apply a full framework of capital and disclosure requirements to all Canadian solo legal entity FRIs within groups. There is scope for strengthening OSFI's approach in the area of investments. The provincial authorities should continue to harmonize their COB regimes, while ensuring adequate supervisory resources for effective $C O B$ supervision. It is essential that FSCO be equipped with adequate resources and financial capacity to deal with the size and diversity of the Ontario marketplace.

\begin{tabular}{|c|c|c|}
\hline \multicolumn{3}{|c|}{ Table 3. Summary of Compliance with the ICPs } \\
\hline & Insurance Core Principle & Overall Comments \\
\hline & $\begin{array}{l}\text { Objectives, Powers and } \\
\text { Responsibilities of the } \\
\text { Supervisor }\end{array}$ & $\begin{array}{l}\text { The responsibilities for the regulation and supervision of the } \\
\text { insurance sector are shared between the federal and provincial } \\
\text { authorities, each with a clearly defined mandate and objectives under } \\
\text { the relevant primary legislation. OSFI, AMF and FSCO have taken } \\
\text { action to recommend amendments to the relevant legislation when } \\
\text { they identified conflicts between legislation and supervisory } \\
\text { objectives. While the supervisors are authorized to issue guidance on } \\
\text { their supervisory expectations, they are not empowered to issue } \\
\text { directly legally binding rules. OSFI has not been delegated powers to } \\
\text { make binding rules. The insurance legislation also does not explicitly } \\
\text { address the objectives and authority for the supervision of insurance } \\
\text { groups. Close coordination between the prudential and CoB } \\
\text { supervisors is critical to achieving the overall objectives of insurance } \\
\text { supervision, including striking an appropriate balance between the } \\
\text { supervisory objectives of prudential and COB supervision. }\end{array}$ \\
\hline & Supervisor & $\begin{array}{l}\text { OSFI, AMF and FSCO have robust accountability frameworks and are } \\
\text { generally transparent in how they discharge their supervisory } \\
\text { responsibilities. While the supervisors have adequate delegated } \\
\text { authority to conduct supervision within the parameters set out in the } \\
\text { relevant legislation, their operational autonomy is affected by the } \\
\text { statutory roles of the Minister (OSFI) and MFEQ (AMF) in institution- } \\
\text { specific supervisory decisions or to take account of policy statements }\end{array}$ \\
\hline
\end{tabular}




\begin{tabular}{|c|c|c|}
\hline & & $\begin{array}{l}\text { issued by the Minister (FSCO). The legal framework and operational } \\
\text { safeguards for the protection of confidential information are strong. } \\
\text { The heads of the supervisory agencies and their staff members are } \\
\text { required to observe high ethical standards including effective } \\
\text { management of conflicts of interest and they have adequate legal } \\
\text { protection. } \\
\text { OSFI and FSCO are subject to government-wide fiscal restraints and } \\
\text { guidelines on their discretion to allocate resources and the AMF's } \\
\text { budget and fees are subject to government approval. While the } \\
\text { removal of the Superintendent of OSFI is subject to a parliamentary } \\
\text { process that ensures accountability, there is no requirement for the } \\
\text { reasons for the removal of the President and CEO of AMF and the } \\
\text { superintendent of FSCO to be published. There is scope for OSFI to } \\
\text { enhance the transparency of its different approaches to supervising } \\
\text { insurance groups. }\end{array}$ \\
\hline & $\begin{array}{l}\text { Information Exchange and } \\
\text { Confidentiality } \\
\text { Requirements }\end{array}$ & $\begin{array}{l}\text { All three supervisors are empowered to obtain and exchange } \\
\text { information with relevant supervisors and authorities subject to } \\
\text { confidentiality, purpose and use requirements. They have a wide } \\
\text { network of bilateral MoUs and OSFI is a signatory to the IAIS } \\
\text { Multilateral MoU. The existence of an MoU is not a prerequisite for } \\
\text { information exchange and strict reciprocity is not required. OSFI's } \\
\text { policy is to limit the sharing of written confidential information unless } \\
\text { a formal arrangement is in place and this has not posed practical } \\
\text { issues as it has a wide network of MoUs and proactively initiates MoU } \\
\text { discussions with relevant supervisors. }\end{array}$ \\
\hline & Licensing & $\begin{array}{l}\text { The licensing process for FRIs involves a three-stage process: a) } \\
\text { approval by the Minister to incorporate or continue operations under } \\
\text { the ICA; b) an Order to commence and carry on business issued by } \\
\text { OSFI; and c) licensing by the relevant provincial supervisors in all the } \\
\text { provinces that it intends to conduct insurance business. Foreign } \\
\text { insurers intending to establish branches must obtain an Order from } \\
\text { OSFI if they intend to "insure in Canada a risk", along with a provincial } \\
\text { license and they are required to include a statement in all policy } \\
\text { documents that the policy was issued in the course of their insurance } \\
\text { business in Canada. The criteria and procedures for the approval by } \\
\text { the Minister and OSFI are clear and transparent. The process involves } \\
\text { significant interaction with the applicants and the relevant home } \\
\text { supervisors (if applicable) and OSFI typically conducts a pre- } \\
\text { commencement on-site review of the FRI or branch before issuing } \\
\text { the Order to Commence and Carry on Business or an Order to Insure } \\
\text { in Canada Risks. Licensing criteria and processes adopted by AMF }\end{array}$ \\
\hline
\end{tabular}




\begin{tabular}{|c|c|c|}
\hline & & $\begin{array}{l}\text { and FSCO are in line with international best practices, supported by a } \\
\text { harmonised application form developed by the CCIR. }\end{array}$ \\
\hline & Suitability of Persons & $\begin{array}{l}\text { The ICA provides for the eligibility of Responsible Persons, which is } \\
\text { supplemented by OSFI's guidelines on its expectation for } \\
\text { FRIs/branches to establish and implement assessment policies and } \\
\text { procedures to assess suitability of persons, including the scope of } \\
\text { persons to be assessed. OSFI generally relies on the internal } \\
\text { processes of FRIs/branches and may require a FRI/branch to } \\
\text { demonstrate the suitability of persons where warranted. Change in } \\
\text { Responsible Persons (defined as a member of the Board or a Senior } \\
\text { Officer) must be notified to OSFI. OSFI is empowered to disqualify or } \\
\text { remove persons found not suitable to hold the relevant positions. }\end{array}$ \\
\hline & $\begin{array}{l}\text { Changes in Control and } \\
\text { Portfolio Transfers }\end{array}$ & $\begin{array}{l}\text { The ICA sets clear ownership and control thresholds above which } \\
\text { approval is required. The Minister is vested with the authority to } \\
\text { approve proposals to acquire or increase significant ownership or } \\
\text { interest in a FRI, based on essentially the same criteria as those for } \\
\text { the incorporation of FRIs. While FRIs are not explicitly required to } \\
\text { notify OSFI in the case of a significant decrease in the ownership by a } \\
\text { person(s) below the pre-determined control level, such cases may be } \\
\text { identified through OSFI's supervisory process. FRIs need to obtain } \\
\text { approvals from the Minister to transfer all or substantially all of their } \\
\text { business to another insurer while the Superintendent approves less } \\
\text { substantial portfolio transfers. }\end{array}$ \\
\hline & Corporate Governance & $\begin{array}{l}\text { The ICA and OSFI Corporate Governance Guideline provide for an } \\
\text { extensive framework of standards on corporate governance of FRIs. } \\
\text { While certain requirements are set out in law and apply to all FRIs, } \\
\text { including a requirement to establish an audit committee with } \\
\text { prescribed responsibilities, the Guideline recognizes the need for } \\
\text { corporate governance arrangements to reflect the circumstances of } \\
\text { individual FRIs. OSFI monitors and assesses corporate governance as } \\
\text { part of its supervisory approach, looking both at compliance with } \\
\text { minimum standards (including Chair/CEO separation as well as the } \\
\text { role of the audit committee) and at the effectiveness of corporate } \\
\text { governance in practice. OSFI's expectations of the larger FRIs are in } \\
\text { line with international practice in areas such as the need for a board } \\
\text { Risk Committee and CRO; and OSFI also devotes resources and } \\
\text { specialist expertise to oversight of governance at the large insurance } \\
\text { groups. } \\
\text { AMF has published guidelines in this area and assesses governance in } \\
\text { its supervisory work. FSCO's oversight work in this area primarily } \\
\text { makes use of monitoring tools such as industry wide assessment }\end{array}$ \\
\hline
\end{tabular}




\begin{tabular}{|c|c|c|}
\hline & & $\begin{array}{l}\text { questionnaires followed by selected field examinations in targeted } \\
\text { risk areas. While FSCO has not published guidelines on governance, it } \\
\text { is able to rely on OSFI and AMF Guidelines to set general } \\
\text { expectations since the majority of insurance business in Ontario is } \\
\text { transacted by companies subject to solvency regulations by OSFI or } \\
\text { AMF. }\end{array}$ \\
\hline & $\begin{array}{l}\text { Risk Management and } \\
\text { Internal Controls }\end{array}$ & $\begin{array}{l}\text { OSFI has an extensive framework of requirements for risk } \\
\text { management and control functions at FRIs and oversees the } \\
\text { effectiveness of the arrangements as part of its supervision program. } \\
\text { A particular emphasis of the approach is on ensuring that there is a } \\
\text { CRO at the major institutions with appropriate stature and authority, } \\
\text { including a reporting line to the board. OSFI's approach also provides } \\
\text { for a balance between ensuring appropriate stature and significance } \\
\text { for actuarial work, supported by the key role of the AA, and fully } \\
\text { embedding actuarial work and decisions within the overall corporate } \\
\text { governance framework. }\end{array}$ \\
\hline & $\begin{array}{l}\text { Supervisory Review and } \\
\text { Reporting }\end{array}$ & $\begin{array}{l}\text { OSFI's risk-based Supervisory Framework facilitates structured and } \\
\text { comprehensive supervisory risk assessment as well as prompt and } \\
\text { consistent supervisory actions. While OSFI collects extensive } \\
\text { regulatory, statistical and capital related information at the } \\
\text { consolidated level and at the solo FRI level, some of the information } \\
\text { collected is less granular on a non-consolidated basis. There is no } \\
\text { standardized reporting of intra-group transactions. In addition, the } \\
\text { current scope of related party transactions for the purposes of } \\
\text { reporting to OSFI by FRIs' Conduct Committees is narrower than } \\
\text { intra-group transactions with broad exemptions including reinsurance } \\
\text { transactions (ICP 23). There are clear scoping statements and } \\
\text { processes for onsite reviews. OSFI issues annual Supervisory Letters } \\
\text { on its key findings and recommendations and Interim Letters, as } \\
\text { appropriate. The Supervisory Framework helps to ensure that } \\
\text { supervisory activities are documented and followed through in a } \\
\text { timely manner. OSFI is empowered to inspect service providers of } \\
\text { outsourced functions and has conducted such inspections. } \\
\text { Both AMF and FSCO adopt a risk-based approach to CoB supervision. } \\
\text { AMF's Supervisory Framework is closely aligned with international } \\
\text { best practices. AMF has authorized the CAD to conduct inspections of } \\
\text { small-scale P\&C intermediaries and claims adjustment firms, subject } \\
\text { to its oversight. Constrained by limited resources, FSCO adopts both } \\
\text { reactive and targeted industry-wide risk-based approach to CoB } \\
\text { supervision. }\end{array}$ \\
\hline & Preventive and Corrective & The supervisors are empowered to take action against a person who \\
\hline
\end{tabular}




\begin{tabular}{|c|c|c|}
\hline & Measures & $\begin{array}{l}\text { conducts insurance business without the necessary Order from OSFI } \\
\text { or license from AMF or FSCO. OSFI's Supervisory Framework supports } \\
\text { early intervention and OSFI has published guidance on its approach } \\
\text { to taking progressive escalation of actions or remedial measures at } \\
\text { each stage of the intervention ratings assigned to FRIs and severity of } \\
\text { the situation. OSFI has adequate powers to initiate timely and } \\
\text { proportionate preventive and corrective measures where FRIs are } \\
\text { unable or unwilling to adequately address supervisory concerns. } \\
\text { Similarly, AMF and FSCO have adequate legal authority to take } \\
\text { preventive and corrective measures relating to CoB issues. }\end{array}$ \\
\hline 11. & Enforcement & $\begin{array}{l}\text { All three supervisors have adequate legal authority and tools to take } \\
\text { enforcement actions and impose sanctions, in a progressive approach } \\
\text { that is commensurate with the severity of the offence. There are } \\
\text { established internal guides as well arrangements to ensure consistent } \\
\text { and fair application of enforcement actions and sanctions. In practice, } \\
\text { OSFI rarely takes enforcement actions as its moral suasion has been } \\
\text { effective. FSCO and AMF have taken a number of enforcement } \\
\text { actions on market conducts breaches. }\end{array}$ \\
\hline 12. & $\begin{array}{l}\text { Winding-up and Exit from } \\
\text { the Market }\end{array}$ & $\begin{array}{l}\text { There are extensive provisions in the legislation for the authorities to } \\
\text { manage the exit from the market of an insurance company, including } \\
\text { Canadian branches of foreign insurers, in an orderly manner. These } \\
\text { also provide for policyholders to rank above general (unsecured) } \\
\text { creditors. For L\&H insurance, these provisions are substantially } \\
\text { untested for many years (notwithstanding the failure of a small } \\
\text { provincially-incorporated company in 2012). In P\&C insurance, the } \\
\text { arrangements have been more often tested, although most failures } \\
\text { have been smaller, provincially regulated companies. }\end{array}$ \\
\hline 13. & $\begin{array}{l}\text { Reinsurance and Other } \\
\text { Forms of Risk Transfer }\end{array}$ & $\begin{array}{l}\text { OSFI's guidelines on reinsurance, recently reissued after a full review, } \\
\text { set out extensive standards on the management of reinsurance, with } \\
\text { an emphasis on management taking responsibility for assessing } \\
\text { reinsurance counterparties rather than relying on third parties, setting } \\
\text { limits in line with risk appetite and documenting the approach in a } \\
\text { board-approved statement. OSFI's policy to require collateral to be } \\
\text { posted by foreign reinsurers as a condition of credit being taken for } \\
\text { reinsurance enhances the security of these arrangements but needs } \\
\text { to be accompanied both by requirements on FRIs to evaluate the } \\
\text { residual risks and by systematic evaluation by OSFI of the supervision } \\
\text { arrangements for the foreign reinsurers. }\end{array}$ \\
\hline 14. & Valuation & $\begin{array}{l}\text { The requirements on valuation of technical provisions and assets } \\
\text { provide a comprehensive framework of standards, including a } \\
\text { consistent economic basis for valuation across the balance sheet and }\end{array}$ \\
\hline
\end{tabular}




\begin{tabular}{|c|c|}
\hline & $\begin{array}{l}\text { margins for adverse deviation. While the approach is principles-based } \\
\text { and provides for significant discretion to be exercised by the AA, it is } \\
\text { underpinned by professional and regulatory requirements applying to } \\
\text { the AA and a framework of oversight, peer review and audit } \\
\text { requirements. The approach has been adapted where areas of } \\
\text { weakness were highlighted by the financial crisis. Nonetheless, there } \\
\text { remain aspects of the approach (allowances for credit spreads and } \\
\text { the extent of discretion in relation to non-fixed income investments) } \\
\text { where strengthening of the actuarial standards is appropriate. It is } \\
\text { also important that the oversight, peer review and audit requirements } \\
\text { continue to provide a robust challenge to the assumptions and } \\
\text { methods used by actuaries. }\end{array}$ \\
\hline 15. Investment & $\begin{array}{l}\text { The framework of legislation and guidelines on FRIs' investments } \\
\text { includes restrictions on certain types of investment, hard limits on } \\
\text { particular asset classes (though with exemptions for the largest } \\
\text { insurers) and high-level requirements to manage investments in a } \\
\text { prudent manner. These standards are complemented by the valuation } \\
\text { and capital requirements that incentivise FRIs to undertake asset and } \\
\text { liability matching and which require capital to be held in relation to } \\
\text { particular classes of asset risk. In the nature of the valuation } \\
\text { requirements, which allow FRIs to take account of the current yields } \\
\text { on assets in their assumptions about reinvestment rates, FRIs have } \\
\text { some incentives to invest in higher yielding assets for asset and } \\
\text { liability management purposes and this needs to be accompanied by } \\
\text { a more robust framework of requirements on FRIs' investment in } \\
\text { higher risk and more complex assets. }\end{array}$ \\
\hline $\begin{array}{l}\text { 16. Enterprise Risk } \\
\text { Management for Solvency } \\
\text { Purposes }\end{array}$ & $\begin{array}{l}\text { OSFI has an extensive set of guidelines that require FRIs to identify, } \\
\text { measure and manage all material risks, taking into account the results } \\
\text { of stress testing. These guidelines also require insurers to make their } \\
\text { own evaluation of their capital needs, based on their own assessment } \\
\text { of risks. OSFI's guideline on ORSA requirements, currently a draft } \\
\text { standard which is scheduled to be implemented in 2014, will } \\
\text { consolidate and extend this framework, emphasising the need for } \\
\text { FRIs to take their own view of overall capital needs, independent of } \\
\text { the regulatory framework-which is critical to ensuring that OSFI has } \\
\text { the necessary input into its own process for evaluating the individual } \\
\text { capital adequacy of FRIs. Full implementation of the approach will } \\
\text { take some time, even if FRIs are already working on improving their } \\
\text { framework based on the draft guideline. }\end{array}$ \\
\hline 17. Capital Adequacy & $\begin{array}{l}\text { The capital requirements for FRIs are comprehensive, capturing all } \\
\text { material risks as well as requiring FRIs to hold capital for risks not }\end{array}$ \\
\hline
\end{tabular}




\begin{tabular}{|c|c|}
\hline & $\begin{array}{l}\text { covered by standard requirements. The approach is risk-sensitive and } \\
\text { encompasses operational risk, although on the basis of additional } \\
\text { buffers rather than detailed quantitative requirements. OSFI also } \\
\text { requires FRIs to calculate internal capital targets and uses their } \\
\text { oversight of this process to assess whether capital of FRIs fully reflects } \\
\text { their individual risks. OSFI allows firms to use internal models in } \\
\text { limited areas, but applies a full model approval process and ongoing } \\
\text { monitoring. } \\
\text { A distinguishing feature and a strength of OFSI's regime is its } \\
\text { application on a consolidated basis to each operating FRI, even } \\
\text { encompassing their foreign insurance operations. However, because } \\
\text { of the limitations on its powers over unregulated companies within a } \\
\text { group, OSFI's approach to the application of its capital requirements } \\
\text { on a consolidated basis varies across groups. Although OSFI is } \\
\text { developing a set of requirements for solo legal entity capital } \\
\text { requirements to apply to material solo FRIs, the full capital } \\
\text { requirements are not applied at the level of the legal entity. }\end{array}$ \\
\hline 18. Intermediaries & $\begin{array}{l}\text { The provincial supervisors have been collaborating to promote } \\
\text { harmonization of the different regulatory regimes for intermediaries, } \\
\text { with CISRO taking a proactive role. Both AMF and FSCO supervise a } \\
\text { large population of intermediaries in their respective jurisdictions. } \\
\text { While the regulatory regimes for intermediaries in Ontario and } \\
\text { Québec are broadly similar, there are differences in key areas e.g. the } \\
\text { use of SROs. Licensing criteria and on-going compliance } \\
\text { requirements are clearly established under both regimes, supported } \\
\text { by supervisory guidance. Regulatory information is largely based on } \\
\text { information submitted for renewals of licenses/certificates, } \\
\text { supplemented by third party notifications e.g. from SROs or } \\
\text { complainants. Most intermediaries are individuals and there are no } \\
\text { explicit corporate governance requirements for intermediaries } \\
\text { although incorporated entities are subject to general obligations } \\
\text { under the relevant general corporate laws. However, insurance laws } \\
\text { impose duties and prohibitions on the actions of intermediaries. } \\
\text { AMF conducts routine inspections of intermediaries, generally } \\
\text { targeting intermediaries with higher risks. FSCO's supervisory } \\
\text { approach is more reactive, mainly in response to self-declarations of } \\
\text { non-compliance or complaints/information received. While Ontario } \\
\text { laws requires that insurers screen and monitor their agents and report } \\
\text { non-compliance, this is complicated by the fact that a significant } \\
\text { number of agents represent more than one insurer or place business } \\
\text { through MGAs. While the CLHIA has established industry guidelines }\end{array}$ \\
\hline
\end{tabular}




\begin{tabular}{|c|c|}
\hline & $\begin{array}{l}\text { on MGAs, the trade-offs arising from a self-regulatory approach have } \\
\text { to be weighed carefully and on an on-going basis. }\end{array}$ \\
\hline 19. Conduct of Business & $\begin{array}{l}\text { At the national level, CCIR coordinates and promotes the } \\
\text { harmonization of the CoB regimes of provincial supervisors and has } \\
\text { developed a risk-based supervision approach, which is adopted by } \\
\text { FSCO and played a large part in the development of AMF's } \\
\text { framework. The JFFMR has reviewed insurers' and mutual funds' } \\
\text { processes when designing and developing new products, with the } \\
\text { goal of ensuring that the interests of different types of consumers are } \\
\text { taken into consideration. Insurance industry associations have also } \\
\text { taken initiatives to ensure their members act with due skill, care and } \\
\text { diligence including voluntary codes of conduct. There is a nation- } \\
\text { wide Complaint Reporting System accessible by all provincial } \\
\text { supervisors (except British Columbia). } \\
\text { The IA, DA and related regulations as well as AMF guidelines provide } \\
\text { for fair treatment of policyholders and disclosure requirements for } \\
\text { insurers and intermediaries in Québec. These include promoting a } \\
\text { culture of fair treatment of customers, product development and } \\
\text { promotion, timely and equitable handling of claims and complaints } \\
\text { and policy servicing obligations. The privacy of customers has } \\
\text { statutory protection. } \\
\text { FSCO and RIBO have established CoB requirements through to the } \\
\text { point all obligations under a contract have been satisfied. Due to } \\
\text { resource constraints, FSCO and RIBO have limited ability to } \\
\text { consistently monitor the timing, delivery, and content of point of sale } \\
\text { material. They have issued limited supervisory guidance (except for } \\
\text { motor insurance) and leverage stakeholder associations to develop } \\
\text { their own codes of conduct. As the vast majority of insurers operating } \\
\text { in Ontario are FRIs, FSCO relies heavily on OSFI's due diligence with } \\
\text { respect to corporate governance and background checks on directors } \\
\text { and senior management of FRIs. }\end{array}$ \\
\hline 20. Public Disclosure & $\begin{array}{l}\text { At the group consolidated level, disclosure requirements are } \\
\text { extensive, but these are not fully matched by comprehensive } \\
\text { requirements applying to regulated legal entities at the solo level, } \\
\text { especially with respect to disclosure of information on the capital of } \\
\text { FRIs. The application of the IFRS framework to all FRIs and not only to } \\
\text { public companies has ensured that consistent standards are applied } \\
\text { across firms. However, reliance on IFRS also risks there being some } \\
\text { gaps between the disclosure requirements of the standard-setters } \\
\text { and the requirements applicable to FRIs to meet regulatory } \\
\text { objectives, including making information available to policyholders. }\end{array}$ \\
\hline
\end{tabular}




\begin{tabular}{|c|c|}
\hline & $\begin{array}{l}\text { OSFI and the Actuarial Standards Board have filled these gaps to a } \\
\text { large extent through their guidelines and the Standards of Practice, } \\
\text { but the reliance on IFRS creates risk of divergence which requires } \\
\text { careful monitoring. }\end{array}$ \\
\hline $\begin{array}{l}\text { 21. Countering Fraud in } \\
\text { Insurance }\end{array}$ & $\begin{array}{l}\text { There is a well-developed framework of legislation at federal and } \\
\text { provincial levels enabling criminal and regulatory authorities to } \\
\text { detect, investigate and apply sanctions in cases of insurance fraud. } \\
\text { Cooperation has been evident, especially in the area of motor fraud } \\
\text { in Ontario, which has also been the subject of an initiative by the } \\
\text { provincial government (an Anti-Fraud Task Force) to address the } \\
\text { issues. Regulatory requirements on insurers are set out clearly in } \\
\text { relevant laws and guidelines. Fraud controls are included in } \\
\text { supervisory work by OSFI, AMF and FSCO, where considered material } \\
\text { under the risk-based approach taken by the three supervisors. FSCO } \\
\text { is appropriately making motor fraud controls a high priority. } \\
\text { Enforcement action has been taken in practice. }\end{array}$ \\
\hline $\begin{array}{l}\text { 22. Anti-Money Laundering } \\
\text { and Combating the } \\
\text { Financing of Terrorism }\end{array}$ & $\begin{array}{l}\text { OSFI, AMF and FSCO are not designated competent authorities for } \\
\text { AML/CFT. However, all three supervisors have arrangements in place } \\
\text { to communicate with FINTRAC, the Financial Intelligence Unit for } \\
\text { Canada and competent authority for AML/CFT regulation, in relation } \\
\text { to AML/CFT arrangements that encompass all L\&H insurers, whether } \\
\text { incorporated by OSFI or a provincial authority; and intermediaries. } \\
\text { Information exchange takes place in practice and there is an } \\
\text { awareness of ML/FT risks and vulnerabilities and of the importance of } \\
\text { securing a high degree of compliance by regulated entities. } \\
\text { Information exchange with foreign authorities is dealt with mainly by } \\
\text { and through FINTRAC, but OSFI may also exchange information } \\
\text { directly in connection with its work on the overseas operations of } \\
\text { Canadian L\&H FRIs. OSFI and AMF go beyond the requirements of } \\
\text { ICP22 by establishing specific guidelines setting out their } \\
\text { expectations of insurers (there is no similar guidance for } \\
\text { intermediaries); and by building AML/CFT compliance into their } \\
\text { supervisory work. OSFI has a particularly extensive program of } \\
\text { supervision work and a specialist unit to support it. AMF and FSCO } \\
\text { take a risk-based and proportionate approach to the supervision of } \\
\text { L\&H insurers, reflecting both international standards and the work of } \\
\text { OFSI on FRIs and overall responsibilities of FINTRAC. }\end{array}$ \\
\hline 23. Group-wide Supervision & $\begin{array}{l}\text { The ICA, IA and OIA do not have an explicit definition of insurance } \\
\text { group nor the scope of an insurance group for the purpose of group- } \\
\text { wide supervision. Nonetheless, the three supervisors address certain } \\
\text { elements of group-wide supervision within the parameters of their }\end{array}$ \\
\hline
\end{tabular}




\begin{tabular}{|c|c|}
\hline & 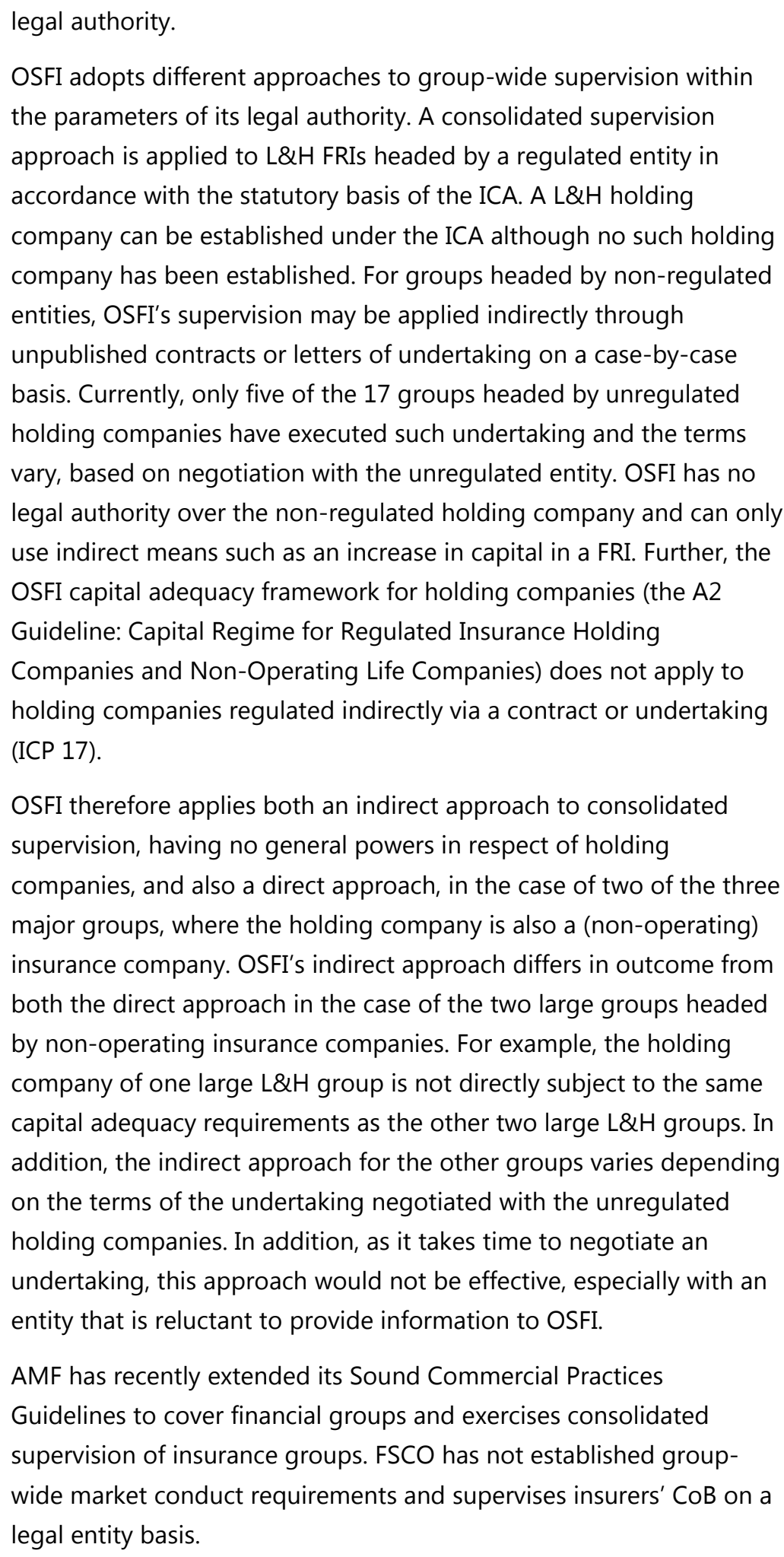 \\
\hline $\begin{array}{l}\text { 24. Macroprudential } \\
\text { Surveillance and Insurance } \\
\text { Supervision }\end{array}$ & $\begin{array}{l}\text { OSFI has a well-developed framework of macroprudential supervision } \\
\text { that seeks to integrate the supervisory framework for individual FRIs } \\
\text { with a market wide view of key risks and a capacity to respond to }\end{array}$ \\
\hline
\end{tabular}




\begin{tabular}{|c|c|}
\hline & $\begin{array}{l}\text { emerging issues, through supervisory action and by escalation for } \\
\text { discussion with other federal agencies. }\end{array}$ \\
\hline $\begin{array}{l}\text { 25. Supervisory Cooperation and } \\
\text { Coordination }\end{array}$ & $\begin{array}{l}\text { OSFI has in place coordination arrangements with other domestic and } \\
\text { foreign supervisors that facilitate effective supervision. Domestically, } \\
\text { OSFI (the Superintendent) chairs the FISC and collaborates closely } \\
\text { with FISC members at the federal level while the CCIR facilitates the } \\
\text { coordination amongst OSFI and provincial supervisors. At the } \\
\text { international level, OSFI is the GWS for all the large Canadian, } \\
\text { internationally-active life insurers and has initiated a variety of } \\
\text { supervisory colleges. OSFI also contributes actively to relevant } \\
\text { supervisory colleges as a host supervisor. }\end{array}$ \\
\hline $\begin{array}{l}\text { 26. Cross-border Cooperation } \\
\text { and Coordination on Crisis } \\
\text { Management }\end{array}$ & $\begin{array}{l}\text { While OSFI's approach to management of a cross-border crisis is } \\
\text { untested in practice, it has put in place a network of information- } \\
\text { sharing arrangements (in addition to its commitments under the IAIS } \\
\text { MMOU) as well as mechanisms for cooperation in practice, including } \\
\text { supervisory colleges that provide a basis for effective coordination in } \\
\text { a crisis. OSFI is well-advanced, by comparison with other jurisdictions } \\
\text { internationally, in applying the framework for recovery planning for } \\
\text { banks to its major insurance groups, although it has not shared these } \\
\text { plans with foreign supervisors as yet. }\end{array}$ \\
\hline
\end{tabular}

\section{E. Recommendations}

\begin{tabular}{|c|c|}
\hline \multicolumn{2}{|c|}{ Table 4. Recommendations to Improve Observance of the ICPs } \\
\hline Insurance Core Principle & Recommendations \\
\hline $\begin{array}{l}\text { 1. Objectives, Powers and } \\
\text { Responsibilities of the } \\
\text { Supervisor }\end{array}$ & $\begin{array}{l}\text { a) Consider the scope to strengthen regulation by providing delegated } \\
\text { powers, as are available to many regulatory authorities } \\
\text { internationally, to issue enforceable rules by administrative means } \\
\text { rather than through legislation; } \\
\text { b) Establish explicit supervisory objectives for group-wide supervision } \\
\text { under the relevant primary legislation, supported by adequate legal } \\
\text { powers to conduct group-wide supervision. }\end{array}$ \\
\hline 2. Supervisor & $\begin{array}{l}\text { a) Update the relevant primary legislations to adopt separate legal } \\
\text { processes for the prudential decisions of OSFI and AMF from the } \\
\text { approval from the executive branch to address national policy } \\
\text { objectives and specify the circumstances for the issuance of policy } \\
\text { statements to FSCO; } \\
\text { b) Consider exempting the supervisors from the government's fiscal } \\
\text { controls and administrative guidance, as in the case of the BOC, to }\end{array}$ \\
\hline
\end{tabular}




\begin{tabular}{|c|c|}
\hline & $\begin{array}{l}\text { strengthen their financial autonomy; } \\
\text { c) Review the adequacy of supervisory resources of FSCO and whether } \\
\text { FSCO should continue to be subject to the hiring controls set by the } \\
\text { Ontario Public Service; } \\
\text { d) Enhance the transparency of OSFI's different approaches to } \\
\text { supervising insurance groups; } \\
\text { e) Establish explicit provisions on public disclosure of the reasons for } \\
\text { removal of the President and CEO of AMF and the Superintendent of } \\
\text { FSCO. }\end{array}$ \\
\hline $\begin{array}{l}\text { 6. Changes in Control and } \\
\text { Portfolio Transfers }\end{array}$ & $\begin{array}{l}\text { Require FRIs to notify OSFI of a significant decrease in the ownership by } \\
\text { a person(s) below the pre-determined control level. }\end{array}$ \\
\hline 7. Corporate Governance & $\begin{array}{l}\text { Set out more extensive guidance on FSCO's own expectations in relation } \\
\text { to corporate governance and market conduct. }\end{array}$ \\
\hline $\begin{array}{l}\text { 9. Supervisory Review and } \\
\text { Reporting }\end{array}$ & $\begin{array}{l}\text { Enhance and standardize regulatory reporting of intra-group } \\
\text { transactions, supported by a clear definition of the scope of intra-group } \\
\text { transactions. OSFI should also review the level of detail of its reporting } \\
\text { requirements applying to solo FRIs. } \\
\text { Equip FSCO with adequate supervisory resources to deal with the size } \\
\text { and diversity of the Ontario marketplace. }\end{array}$ \\
\hline $\begin{array}{l}\text { 10. Preventive and Corrective } \\
\text { Measures }\end{array}$ & $\begin{array}{l}\text { Strike a good balance between timely staging as a result of persistent } \\
\text { concerns, and the need to maintain pressure on the institution to make } \\
\text { meaningful progress over a credible and situation-specific appropriate } \\
\text { timeline in order to exit staging. }\end{array}$ \\
\hline $\begin{array}{l}\text { 12. Winding-up and Exit } \\
\text { from the Market }\end{array}$ & $\begin{array}{l}\text { (a) Examine whether the designation of PACICC by approval of the } \\
\text { Minister under the ICA in the same way as Assuris would help } \\
\text { promote increased cooperation and early exchange of information } \\
\text { between OSFI and the PACICC. } \\
\text { (b) Continue to test procedures for handling a failure of a FRI by further } \\
\text { simulation exercises and the development of recovery plans that is } \\
\text { already underway for the large L\&H companies. }\end{array}$ \\
\hline $\begin{array}{l}\text { 13. Reinsurance and Other } \\
\text { Forms of Risk Transfer }\end{array}$ & $\begin{array}{l}\text { a) Consider adding material on the importance of FRIs assessing and } \\
\text { managing liquidity risks arising from reinsurance cessions when } \\
\text { revising OSFI guidelines; and } \\
\text { b) Enhance OSFI's process for evaluating the supervisory regimes } \\
\text { applying to major unregistered foreign reinsurers so that it explicitly } \\
\text { addresses the supervision of reinsurance in their home jurisdictions. }\end{array}$ \\
\hline 14. Valuation & $\begin{array}{l}\text { Strengthen the valuation standards on credit spreads and non-fixed } \\
\text { income investments, recognizing that the current ASB review of }\end{array}$ \\
\hline
\end{tabular}




\begin{tabular}{|c|c|}
\hline & $\begin{array}{l}\text { reinvestment assumptions for life insurance valuation is already } \\
\text { addressing the issues. }\end{array}$ \\
\hline 15. Investment & $\begin{array}{l}\text { Undertake a review of OSFI's Prudent Person Approach Guideline, to } \\
\text { strengthen the requirements on investments and in particular to add } \\
\text { explicit requirements that FRI invest only in assets whose risks it can } \\
\text { properly assess and manage and on investments in complex or less } \\
\text { transparent forms of instruments. }\end{array}$ \\
\hline $\begin{array}{l}\text { 16. Enterprise Risk } \\
\text { Management for } \\
\text { Solvency Purposes }\end{array}$ & $\begin{array}{l}\text { Finalise OSFI guideline on ORSA requirements, which is currently a draft, } \\
\text { and set expectations for the early phase of implementation work as soon } \\
\text { as possible. }\end{array}$ \\
\hline 17. Capital Adequacy & $\begin{array}{l}\text { (a) Set out details of OSFI's approach to groups headed by holding } \\
\text { companies in the interests of transparency, till such time as OSFI } \\
\text { obtains full powers to apply its regulatory framework to holding } \\
\text { companies. } \\
\text { (b) Consider aligning OSFI's requirements for regulated holding } \\
\text { companies more closely to those for regulated operating companies. } \\
\text { (c) Finalise OSFI's proposed standard for the application of the capital } \\
\text { framework on a solo legal entity level and develop a plan for } \\
\text { publication of the full approach in due course. OSFI should also } \\
\text { establish policy requirements to address, and review its reporting } \\
\text { requirements on intra-group transactions for capital management } \\
\text { purposes (for example, capital transferability within the group). }\end{array}$ \\
\hline 18. Intermediaries & $\begin{array}{l}\text { a) Maintain the positive momentum in promoting appropriate } \\
\text { harmonisation of the regulatory regimes and supervisory practices } \\
\text { with respect to intermediaries across provinces, e.g. regulatory } \\
\text { treatment of client monies; } \\
\text { b) Consider establishing proportionate expectation tailored for } \\
\text { intermediaries, focussing on achieving fair treatment outcome for } \\
\text { policyholders; } \\
\text { c) Implement the recommendations of the CCIR related to the } \\
\text { regulatory treatment of MGAs across provinces; and } \\
\text { d) Ensure that FSCO has adequate resources for effective supervision of } \\
\text { intermediaries. }\end{array}$ \\
\hline 19. Conduct of Business & $\begin{array}{l}\text { Strengthen the current } \mathrm{COB} \text { regimes by: } \\
\text { a) Continuing the proactive initiatives by CCIR and JFFMR to enhance } \\
\text { consistency of COB regulatory regimes across provinces; } \\
\text { b) Empowering FSCO to issue enforceable rules on product } \\
\text { development and promotion as well as require insurers and }\end{array}$ \\
\hline
\end{tabular}




\begin{tabular}{|c|c|}
\hline & $\begin{array}{l}\text { intermediaries to conduct needs analysis before providing advice } \\
\text { and meet policy servicing obligations; and } \\
\text { c) Reviewing the adequacy of supervisory resources of FSCO for } \\
\text { regulatory policy formulation and conduct more proactive CoB } \\
\text { supervision. }\end{array}$ \\
\hline 20. Public Disclosure & $\begin{array}{l}\text { a) the authorities ensure that FRIs publish (in a format readily available } \\
\text { to policyholders as well as market participants generally) both the } \\
\text { information on the financial position of the individual legal entities at } \\
\text { the solo level in addition to group consolidated requirements, and } \\
\text { information about the FRI's capital; and that the application of OSFI's } \\
\text { guidelines clearly extends to cover FRIs on an individual as well as a } \\
\text { consolidated basis; and } \\
\text { b) Maintain the existing process for monitoring IFRS developments to } \\
\text { ensure a timely and appropriate response to these developments and } \\
\text { determine whether new standards or changes to existing standards } \\
\text { have the required impact on disclosure as well as financial soundness } \\
\text { requirements. }\end{array}$ \\
\hline $\begin{array}{l}\text { 21. Countering Fraud in } \\
\text { Insurance }\end{array}$ & $\begin{array}{l}\text { While their enforcement work has included action against intermediaries } \\
\text { in relation to misrepresentation of insurance cover to a customer, } \\
\text { consider the merits of setting out both AMF and FSCO expectations of } \\
\text { intermediaries in the area of fraud controls more clearly. }\end{array}$ \\
\hline $\begin{array}{l}\text { 22. Anti-Money Laundering } \\
\text { and Combating the } \\
\text { Financing of Terrorism }\end{array}$ & $\begin{array}{l}\text { In relation to intermediaries, consider how best AMF and FSCO should } \\
\text { set out their AML/CFT expectations in more detail, drawing on their } \\
\text { supervisory work and experience. }\end{array}$ \\
\hline 23. Group-wide Supervision & $\begin{array}{l}\text { Formulate and implement a clear and consistent regulatory regime for } \\
\text { group-wide supervision under the relevant insurance laws. Key elements } \\
\text { of the regime should cover the scope of group-wide supervision, } \\
\text { including material non-regulated entities; prudential and market conduct } \\
\text { requirements at the group level. } \\
\text { Going forward, supervisors be empowered to take necessary remedial } \\
\text { and enforcement measures at the level of the holding company, in line } \\
\text { with emerging international best practices. }\end{array}$ \\
\hline $\begin{array}{l}\text { 24. Macroprudential } \\
\text { Surveillance and } \\
\text { Insurance Supervision }\end{array}$ & $\begin{array}{l}\text { Priorities which OSFI may want to consider for the future, in addition to } \\
\text { finalizing its approach to potentially systemically important FRIs, include: } \\
\text { a) Ensuring that it has access to data sources and continuing to } \\
\text { develop the international dimension of its macroprudential work } \\
\text { through liaison with other regulators. } \\
\text { b) Considering whether its mainly sector-based approach is adequately }\end{array}$ \\
\hline
\end{tabular}




\begin{tabular}{|c|c|c|}
\hline & c) & $\begin{array}{l}\text { complemented by consideration of linkages between banks and } \\
\text { insurers; and } \\
\text { Extending its consideration of risks arising from system-wide market } \\
\text { conduct issues, including reputational risks from non-compliance by } \\
\text { FRIs and potential conflict between prudential and market conduct } \\
\text { regulation. }\end{array}$ \\
\hline $\begin{array}{l}\text { 26. Cross-border } \\
\text { Cooperation and } \\
\text { Coordination on Crisis } \\
\text { Management }\end{array}$ & In & $\begin{array}{l}\text { leveloping its approach OSFI should: } \\
\text { Continue to carry out crisis management testing and simulations: } \\
\text { extending this to an international group would be an appropriate } \\
\text { next stage; } \\
\text { Ensure that it considers the potential needs in a crisis of supervisors } \\
\text { in jurisdictions where the Canadian company is material and } \\
\text { anticipates these as far as possible; } \\
\text { Review the need for supplementing its existing requirements in } \\
\text { relation to stress testing by explicitly requiring FRIs to establish and } \\
\text { maintain contingency plans and procedures for use in a going- and } \\
\text { gone- concern situation as set out in the ICP. }\end{array}$ \\
\hline
\end{tabular}

\section{F. Authorities' Response}

46. The Canadian authorities wish to express their appreciation to the IMF and its assessment team for their assessment of the Canadian insurance sector. The Canadian authorities share the view that Canada has a high level of observance with the Insurance Core Principles (ICPs).

47. Canada is highly committed to the FSAP process and the insights that the IMF can provide with respect to a country's financial sector through this process. Canada fully agrees that it is important to continually review and seek to improve the regulatory framework and supervision practices.

48. The IMF has made a number of observations and recommendations, which could further enhance the high degree of compliance with the ICPs.

\section{These recommendations will be given consideration by the relevant federal and}

provincial authorities, having due regard to the various initiatives currently planned or underway, and taking into account the features of the Canadian regime that contributed to the performance of the Canadian insurance system during and post-crisis. It is noted that some recommendations are within the scope and mandate of regulators and others are subject to decisions by different levels of government. 
50. Of note, are the recommendations from the IMF on Principle $\mathbf{2 3}$ (but carried throughout the assessment) related to group-wide supervision, which advises that there be a legislated definition of the scope of group-wide supervision, and that authorities empower supervisors to take necessary remedial and enforcement measures at the level of the holding company, in line with emerging best practices. For future assessments, the IMF may wish to consider bringing more clarity to the basis on which this principle is assessed, given that the ICP and the related standards appear to accept indirect authority over insurance groups, as opposed to direct legislated authority, as the current international standard. We also note that the principle itself is under review internationally.

51. The introduction of ICPs dealing with market conduct issues is relatively new. As a result there is a learning curve to understand how the IMF contemplates that specific standards should be implemented. As the ICPs and assessment techniques evolve, it will be important to balance consideration of process with consideration of outcomes achieved. Past experience has not demonstrated a history of significant unaddressed market conduct problems in Canada.

\section{ASSESSMENT OF THE IOSCO PRINCIPLES AND OBJECTIVES OF SECURITIES REGULATION}

\section{A. Summary}

52. The Canadian framework for the regulation and supervision of securities markets demonstrates a high level of implementation of the IOSCO Principles. ${ }^{11}$ The securities regulatory agencies have been given broad powers to regulate and supervise the markets. Furthermore, in a few areas such as enforcement powers, such powers could be considered leading practices. The provincial regulators have increasingly achieved a high degree of harmonization of their regulatory frameworks and significant efforts have been made at the supervisory front to coordinate, and streamline processes and procedures and to achieve convergence in supervisory practices. Robust arrangements have also been developed for the supervision of many categories of market participants, and use of enforcement powers by the largest provincial regulators has been strengthened significantly.

\section{Despite these gains, developing an integrated and robust view of risks to support} supervisory actions remains a key challenge. Further action would be beneficial on several fronts, including enhancing coordination between the various regulators; building additional specialized staffing capacity; improving the use of quantitative analysis; and increasing the number of on-site inspections. Use of enforcement powers in connection with criminal offenses remains a second key challenge The SROs have taken important steps to ensure that they have in place strong enforcement strategies, in particular in connection with compliance reviews, but it is important that such efforts continue. Finally, the securities regulators should continue to take steps to ensure timely

\footnotetext{
${ }^{11}$ The assessment was conducted by Ana Carvajal (IMF).
} 
decision making in policy formulation. The current governance arrangements, based on a consensus building approach across several entities, might affect timeliness of decision making.

\section{B. Introduction and Scope}

54. A targeted assessment of the Canadian Securities Market was conducted June 3-28, 2013, as part of the Financial Sector Assessment Program by Ana Carvajal, Monetary and Capital Markets Department. A full assessment was conducted in 2007 based on the methodology approved by IOSCO in 2003. As a result Canada met the minimum threshold for a targeted assessment. Based on the due diligence ${ }^{12}$ conducted the assessment covered principles $1,2,3,6,7$, $8,9,12,19,20,22,23,24,28,29,30,31,32,34$, and 35 in their entirety while principles 25 and 37 were partially reassessed ${ }^{13}$. Nothing in the due diligence suggested the need to reassess the remaining principles. The guidance for targeted assessments requires the assessor to carry over the description of the principles that have not been assessed in order to provide a complete view.

55. Such due diligence took into consideration (i) risks and vulnerabilities of the securities markets in Canada, (ii) regulatory developments that have taken place in Canada since 2007, (iii) areas where deficiencies were found in 2007, (iv) new areas of emphasis in the new IOSCO Principles and Methodology, ${ }_{1}{ }^{4}$ and (v) the lessons from the crisis, both in terms of areas that require deeper attention as well as in regard to the need for assessors to take a more critical look at both the regulations in place to determine whether they are adequately capturing the risks of the system, and the intensity of supervision and enforcement, to determine the extent to which the regulatory framework is being implemented in practice. Information and Methodology Used for the Assessment.

\section{The assessment was conducted based on the IOSCO Principles and Objectives of} Securities Regulation approved in 2010 and its Methodology adopted in 2011. Principle 38 is not assessed as this Principle now is covered under the Principles for Financial Market Infrastructure; as a result issues related to CDCC as an SRO are not covered in this assessment.

\footnotetext{
12 The regulatory authorities provided two supporting documents: (i) a report on major regulatory developments that occurred after the 2007 assessment, and (ii) a principle by principle matrix with their views on whether the corresponding principle required reassessment or not, and the rationale for their views. In addition, the assessor conducted independent research on potential areas of concern based on publicly available information, and held discussions with the authorities. Based on this due diligence a proposal of scope was submitted by the mission to the authorities, who accepted it.

${ }^{13}$ Initially principles 1, 2, 3, 29, 30, 31, 32 and 35 were selected for partial reassessment; however in practice the scope of the issues selected led to a full reassessment as all the issues included in the methodology were analyzed. The assessment of principle 25 focused on custody requirements; while the assessment of principle 37 focused on failed settlements and shortselling.

${ }^{14}$ The most significant change brought by the revision of the Principles and methodology adopted in 2010-2011 was the addition of eight new principles, while overall the existing principles remained unchanged -although in a few cases additional questions were added to the methodology. In addition, the existing principle 16 was split into two principles (now principles 18 and 21).
} 
57. The recent global financial crisis has reinforced the need for assessments to be more critical, both in terms of the robustness of regulation as well as the intensity of supervision. On the regulatory side, assessors are been required to look more closely at the extent to which regulations in place adequately capture the risk undertaken by different participants. On the supervisory side, assessors are required to look more deeply into the licensing process, the off-site monitoring and onsite inspection programs as well as how the supervisor follows-up on findings, including the use of enforcement actions, to make an informed judgment on the overall quality of supervision. In jurisdictions that rely extensively on SROs such critical analysis has also applied to them. In many jurisdictions this enhanced approach has had an impact on grades. In addition, experience has been gained in connection with principles 6 and 7 which allows assessors to delve deeper into the analysis of the processes in place to identify emerging and systemic risk.

Furthermore through the Assessment Committee, IOSCO itself is developing further guidance to assess these Principles.

58. The assessment largely relies on an analysis of the regulatory framework and supervisory practices of the four largest provinces (Ontario, Québec, British Columbia and Alberta) to draw inferences on the level of implementation of the Principles for the country as a whole, given the challenge of assessing $\mathbf{1 3}$ frameworks. Given that the legal and regulatory framework has been largely harmonized via national instruments and the fact that these four provinces comprise roughly 95 percent of the activity of the Canadian securities market; the assessor believes this to be a reasonable approach. When relevant, the assessor has made the necessary distinctions in the legal and or regulatory framework, and practices of specific regulatory agencies are mentioned to provide examples as to how a particular requirement has been implemented in practice.

59. The assessor relied on (i) a self-assessment and a report on market data, which were prepared by the OSC, AMF, BCSC and ASC; (ii) the review of relevant national instruments, laws, regulations, and other documents provided by the regulatory agencies including registration, inspection and enforcement files; (iii) meetings with the chairs of the OSC and the ASC, the president of the AMF, and the executive director of the BCSC and staff of the OSC, AMF and BCSC, and other public authorities, in particular representatives of Finance Canada; as well as (iv) meetings with SROs (IIROC, MFDA, CSF, MX); CIPF; market participants including securities firms, market operators (both exchanges and ATSs), auditing firms, credit rating agencies and law firms.

60. The assessor wants to thank staff of the OSC, AMF,BCSC, ASC and CSA Secretariat for their full cooperation as well as their willingness to engage in very candid conversations regarding the regulatory and supervisory framework in their provinces. The assessor also wants to extend her appreciation to all other public authorities and market participants with whom she met.

\section{Institutional Setting}

\section{Securities markets in Canada are under a system of provincial regulation and}

supervision. As a result there are 13 regulatory authorities each one administering a separate set of securities laws and regulations. Overall securities legislation in all the provinces and territories have 
the same underlying objectives - the protection of investors and ensuring fair, efficient capital markets-and the regulatory authorities share the same core responsibilities. However, actual regulations developed by each province to address these core set of goals and responsibilities can differ. As a result, the specific powers of the authorities can differ (although a set of basic powers is available to all of them), and in a few instances, the specific requirements for a particular category of market participants can differ (although as will be explained below there is currently a high degree of harmonization).

62. The nature, structure, resources and powers of the provincial regulators vary. The assessor was informed that in particular in the smallest provinces the regulator might still be part of the government, funded by it and with limited resources. That is not the case for the four largest provinces-Alberta, British Columbia, Ontario and Québec-which roughly supervise 95 percent of the market. These regulatory agencies are operationally independent and fully self-funded by levies imposed on market participants. They have comprehensive powers, including rulemaking, registration, recognition, designation, supervision and enforcement authority-not only administrative but also quasi-criminal authority. In the case of the AMF, the adjudication of administrative cases is carried out through an independent tribunal, the Bureau de Décision et de Révision (BDR).

\section{Under the umbrella of the CSA, provincial regulators are seeking to harmonize laws} and regulations and coordinate their supervisory and enforcement activities. The CSA is a nonstatutory association that brings together all Canadian securities regulatory authorities with the objective of improving regulation and supervision of Canadian securities markets. A Secretariat, located in Montreal, was established in 2004. The Secretariat currently has six staff in charge of providing logistical support to the CSA committees and managing national databases in the area of securities markets.

\section{The CSA has undertaken several initiatives to harmonize securities regulation via the} adoption of national (and a few multilateral) instruments. There are currently 40 national instruments and multilateral instruments, covering a wide variety of areas including issuers, CIS, market places and registrants. As confirmed by the authorities and market participants, most aspects of securities regulation have been harmonized. However, there are a few important differences that remain in connection with the enabling legislation for derivatives, certain prospectus exemptions, registration exemptions for EMDs in the northwest jurisdictions, and registration of non-resident Investment Fund Managers (IFMs)s, as will be explained in the assessment.

\section{On the supervisory front, different initiatives have been implemented to eliminate} duplication and ensure coordination. In particular, a passport system has been implemented for issuers, CIS, securities intermediaries and credit rating agencies. Under the passport system a decision to issue a receipt or a registration/designation decision taken by the principal regulator (usually the regulator of the province where the issuer/CIS/securities firm/CRA is domiciled) is automatically extended to the other provinces. Ontario has not joined the passport system; however the provinces created an interface, whereby decisions taken by the OSC as the principal regulator are automatically extended in the rest of the provinces. In cases where Ontario is not the principal 
regulator, the principal regulator acts as the liaison with the issuer/CIS/securities intermediary/CRA so that vis-à-vis the participant the system works as a single "window". The principal regulator approach also applies to on-going supervision, including review of periodic filings and on-site inspections. The provincial regulators have also worked on the development of a coordinated approach for SROs. In the case of IIROC and MFDA coordination is based on a principal regulator approach, whereby one regulator acts as coordinator of actions on behalf of all regulators; and in the case of the exchanges is based on a lead regulator approach, whereby one regulator recognizes the exchange, while the others grant exemptions. In the area of enforcement, regulators have made use of joint investigations, joint adjudications and reciprocal orders to coordinate their actions. Finally, a system of committees serves as a forum to coordinate and discuss topics, including on novel issues, and to set up national priorities.

\section{Provincial regulators rely largely on self-regulatory organizations (SROs) for the} regulation and supervision of the market and its participants. The regulation and supervision of investment dealers and market surveillance of all equity markets is under the Investment Industry Regulatory Organization of Canada (IIROC), the regulation and supervision of mutual fund dealers except in Québec is under the Mutual Fund Dealers Association of Canada (MFDA), mutual fund dealers in Québec are under the supervision of the AMF and the discipline and education of individuals who act on behalf of mutual fund dealers in Québec is a responsibility of the Chambre de la Sécurité Financière (CSF), and all other non-equity exchanges are primarily responsible for market surveillance, including MX and NGX for derivatives markets.

\section{A recent decision of the Supreme Court of Canada ratified the provincial nature of securities regulation but recognized a role for the federal government on "matters of genuine national importance and scope going to trade as a whole in a way that is distinct from provincial concerns, including management of systemic risk and national data collection." ${ }^{15}$}

\section{Market Structure}

\section{Markets}

Equity markets

\section{The total market capitalization of the Canadian equity market at the end of $\mathbf{2 0 1 2}$ was nearly \$2.2 trillion, or about $\mathbf{1 2 1}$ percent of GDP. There are four equity exchanges in Canada:}

\footnotetext{
${ }^{15}$ The decision related to the constitutionality of the federal government's proposed Securities Act, which sought to create a federal regime for securities regulation in Canada. The Supreme Court ruled that the proposed Act was beyond the federal government's powers and therefore unconstitutional. However it noted that "specific aspects of the Act aimed at addressing matters of genuine national importance and scope going to trade as a whole in a way that is distinct from provincial concerns, including management of systemic risk and national data collection, appear to be related to the general trade and commerce power. With respect to these aspects of the Act, the provinces, acting alone or in concert, lack the constitutional capacity to sustain a viable national scheme [...]." Reference Re Securities Act, 2011 SCC 66, [2011]3.
} 
TSX, TSXV, Canadian National Stock Exchange (CNSX), and Alpha Exchange Inc. (Alpha). ${ }^{16}$ There are currently seven ATS trading in equity securities in Canada. There are also three ATS trading debt securities; however, most of the debt trading is done over the counter. There is also one securities lending ATS.

Debt markets

69. The major components of the Canadian bond market are the market for Government of Canada bonds, Canada Mortgage Bonds, provincial bonds and corporate bonds. The nominal value of total bonds outstanding at year-end 2011 amounted to just under $\$ 2.2$ trillion (approximately 122 percent of GDP, both in local and foreign currency). Around one third are corporate bonds, of which a little more than 50 percent was issued by non-financial corporations.

Derivatives markets

70. The MX is Canada's financial derivatives exchange, listing equity, currency, index and interest rate derivatives. The over-the-counter (OTC) derivatives market is concentrated amongst the big six Canadian banks and the majority of transactions involving Canadian market participants are entered into with foreign counterparties. Globally, Canada accounts for US $\$ 18$ trillion in OTC derivatives, or approximately 2.8 percent of the global market in 2012, with interest rate swaps and foreign exchange contracts being the dominant products.

71. The Natural Gas Exchange (NGX) is Canada's largest energy exchange based in Calgary. It provides electronic trading, central counterparty clearing and data services to the North American natural gas, crude oil and electricity markets.

72. Intercontinental Exchange (ICE) Futures Canada is Canada's agricultural exchange. It was established in 1887 as the Winnipeg Grains and Produce Exchange and has been facilitating futures contract trading since 1904.

CIS

73. Canadian investors access the market through a diverse range of product channels, but continue to favor financial advice over making self-directed investment decisions. At the end of 2011, 91 percent of investment fund assets were acquired and held by investors through distribution channels involving the intermediation of an advisor.

74. Mutual funds remain a popular investment vehicle for Canadians, accounting for about 27 percent of total financial wealth in Canada. As of December 2012, the mutual fund industry had assets under management of $\$ 849.7$ billion, surpassing pre-downturn highs. In reaction to the GFC, the fund industry has seen a shift from equity funds to balanced and fixed income funds.

\footnotetext{
${ }^{16}$ Alpha Exchange, formerly Alpha ATS, was recognized as an exchange in April 2012. However it does not presently list issuers' securities for trading.
} 
Money market funds have also experienced a decline of assets, as a reaction of investors to lower yields paid by MMFs relative to their alternatives such as high interest savings accounts.

ETFS

75. While still small, ETFs have grown markedly in recent years. They reached a quoted market value on the TSX of $\$ 56.4$ billion from 265 funds listed in 2012, up from $\$ 19.4$ billion from 77 funds in 2008. At the end of 2012, ETFs accounted for 6 percent of total investment fund and managed fund assets. In addition to Canadian listed ETFs, Canadian retail investors also held $\$ 10.1$ billion in U.S. listed ETFs which represented 16 percent of all ETF investment by Canadians at September 2012.

Hedge funds

The Canadian hedge fund industry is relatively small. Canadian hedge fund assets were estimated at $\$ 31$ billion, or about 2 percent of the global hedge fund industry, which was estimated to be about $\$ 2.6$ trillion in 2012 . The hedge fund industry is concentrated within a few firms.Intermediaries

76. Canada has a system of specialized securities intermediaries. As a result banks and insurance companies that want to provide securities markets services must do it through a subsidiary. There are three main categories: dealers, advisers and investment fund managers (IFMs). Within the dealer category there are five subcategories: investment dealers (IDs), mutual fund dealers (MFDs), scholarship plans dealers, exempted market dealers and restricted dealers. IDs and MFDs must be members respectively of IIROC and MFDA, except mutual fund dealers in Québec which are subject to the oversight of the AMF.

\section{As of December 2012, there were 1,498 active firms registered to carry out investment} activities in Canada, of which 1,365 were headquartered in Canada. There are 202 registered firms that are IIROC members and another 119 are MFDA members. The remaining registrants are directly overseen by the securities regulators. Out of such number 543 were IFMs.

78. Some of the largest securities firms are subsidiaries of major Canadian banks. Further, through their subsidiaries the six major banks play an important role in securities markets. For instance, as of December 2012, the six bank-owned dealers accounted approximately for 80 percent of all trading volume; Canadian bank-owned asset management subsidiaries exercise control of 60 percent of AUM of the top 10 asset management firms and 27 percent of the sector's total AUM; and the subsidiaries of the six Canadian banks accounted for 92 percent of the total number of sales representatives of IDs and 64 percent of the sales representatives for MFDs. ${ }^{17}$

\footnotetext{
${ }^{17}$ This indicator is used as a proxy of number of clients' accounts.
} 


\section{E. Key Findings}

79. Principles related to the regulator-Current governance arrangements in the four regulatory agencies provide them a high degree of independence from the government, while at the same time subject them to strong accountability. The existence of part-time commissioners can pose conflict of interest, which are mitigated by the selection process established in the provinces and on an ongoing basis by the obligation of members to recuse themselves on decisions where they face conflicts. Under the umbrella of the CSA the provincial regulators have made significant progress in coordination and in ensuring a level playing field; however a few challenges remain. They have also made significant progress in the development of arrangements for the identification of emerging and systemic risk, although the availability of data and use of quantitative analysis is currently a challenge. Finally the regulators are aware of key conflicts of interest prevailing in the market, and are currently reviewing the sets of actions needed to address them. Carry from the 2007 assessment: "They are subject to a high degree of transparency, including public consultation on regulations and published policy statements. At the same time, they abide by high standards of ethics that have been codified into an ethics code, with certain reporting obligations. They are active on investor education".

80. Principles for SROs_SROs are subject to recognition based on eligibility criteria that among others address issues of financial viability, capacity to carry out their functions, governance, and fair access. Supervision is based on a set of mechanisms that include off-site reporting, on-site inspections, as well as regular meetings and close contact with SRO staff to discuss ongoing issues. There has been a significant evolution on governance arrangements in all SROs; but some challenges remain vis-à-vis conflict of interest.

81. Principles for enforcement-Canada has established a credible system for the supervision of the market and its participants in which SROs play a significant role. Current arrangements include both offsite monitoring and on-site inspections. While overall the regulatory agencies have in place an adequate risk-based approach to on-site inspections, in the agencies with the largest populations such risk based approach has resulted in a more focused use of on-site inspections. Enforcement by the regulatory agencies has experienced significant progress in recent years and is currently robust. The SROs are taking important steps to ensure timely response of firms to the deficiencies found in their compliance reviews (MFDA) and to strengthen the nexus between their compliance reviews and their enforcement activity (IIROC). Material challenges remain in connection with enforcement of criminal laws by government departments and law enforcement agencies.

Principles for cooperation-Carry from the $\mathbf{2 0 0 7}$ assessment: "The largest regulatory agencies have explicit and comprehensive powers to share information with both local and domestic authorities and can do so without the need of any external approval. The four largest jurisdictions are signatories of the IOSCO Multilateral Memorandum of Understanding (MMoU). They have the power to obtain information that is not in their files on behalf of foreign regulators. They have shown clear a commitment to exchange information and assist other regulatory agencies both domestically and internationally". 
82. Principles for issuers-Carry from a $\mathbf{2 0 0 7}$ assessment: "Issuers are subject to disclosure obligations at the moment of authorization and on an ongoing basis, fully in line with IOSCO standards. The regulatory agencies have developed a system for review of the prospectus as well as continuous disclosure obligations. Liability provisions are in place to ensure issuers' responsibility for the prospectus".

83. Principles for CIS-CIS operators are subject to registration based on fit and proper requirements. While requirements have been harmonized, the process to review applications varies in important ways across provinces. Current arrangements for the supervision of intermediaries which include both off site monitoring as well as on-site inspections-are adequate; however the use of a risk-based approach has resulted in a more focused use of onsite inspections, particularly for the agencies with the largest populations. Hedge Fund managers are subject to the same regulatory regime than other CIS operators. All CIS that are offered to the public are required to have a custodian. Although custody can be provided by a related party, additional safeguards are in place, including the requirement that custodians are themselves regulated entities, the existence of the IRC, and disclosure to investors. Carry from the 2007 assessment . "Public offerings of CIS are subject to disclosure requirements at the moment of authorization and on an ongoing basis, fully in line with IOSCO principles. There are rules in place on separation of assets."

84. Principles for market intermediaries-Market intermediaries are subject to registration based on fit and proper requirements. While requirements have been harmonized, the process to review applications varies in important ways across provinces. Overall requirements are robust, however prudential requirements for investment dealers need to better capture the risks associated with the use of uninvested moneys of clients. Current arrangements for the supervision of intermediaries include both off site monitoring as well as on-site inspections. These arrangements are adequate; however the use of a risk-based approach has resulted in a more focused use of onsite inspections, particularly for the agencies with the largest populations. There are early warning systems in place; however there is a need to improve coordination arrangements in the event of a failure of large investment dealers.

85. Principles for secondary markets-Carry from the $\mathbf{2 0 0 7}$ assessment: "The operation of an exchange is subject to an authorization regime based on eligibility criteria that include financial viability, capacity, governance, and fair access. Alternative Trading Systems (ATS) are regulated as dealers subject to certain market requirements; however the framework allows the regulatory agencies to regulate them as exchanges once they reach a certain threshold. There are plans to deal with market disruptions, although in one of the agencies these should be further developed [...]. The two main clearing entities, one for securities and the other for derivatives, have developed reasonable mechanisms to manage large exposures including selection criteria for clearing members, margins and collateral". There are robust mechanisms in place for market surveillance. Exchanges and ATS are subject to pre-trade and post-trade transparency provisions. Dark orders are allowed; but the current framework incentivizes transparency. Arrangements to minimize failed settlements are reasonable, and there are robust reporting requirements in connection with shortselling. 
Table 5. Summary Table of Implementation of the IOSCO Principles

\begin{tabular}{|c|c|}
\hline Principle & Findings \\
\hline $\begin{array}{l}\text { Principle } 1 . \text { The responsibilities of the Regulator } \\
\text { should be clear and objectively stated. }\end{array}$ & $\begin{array}{l}\text { Securities markets are regulated and supervised at } \\
\text { the provincial level. The responsibilities and } \\
\text { mandate of the four regulatory agencies analyzed } \\
\text { are clearly established by law. There is a high } \\
\text { degree of harmonization of the regulatory } \\
\text { framework for securities markets; although a few } \\
\text { important differences remain. Different } \\
\text { arrangements have been put in place to foster } \\
\text { coordination among the provinces (such as the } \\
\text { committee system of the CSA) and streamline } \\
\text { processes and procedures (such as the passport } \\
\text { system for issuers, CIS registrants and CRAs) and to } \\
\text { achieve convergence in supervisory practices across } \\
\text { the provinces (such as the development of } \\
\text { templates, manuals, and training), though there are } \\
\text { particular areas where differences in supervisory } \\
\text { approaches exist. Vis-à-vis the SROs' supervision, } \\
\text { several coordination mechanisms have been put in } \\
\text { place. All such arrangements should continue to be } \\
\text { strengthened to ensure that a "full" view of risks is } \\
\text { developed. There are also coordination mechanisms } \\
\text { with other financial authorities, via the HoA; } \\
\text { however there is a need to deepen such } \\
\text { arrangements including in connection with crisis } \\
\text { management. }\end{array}$ \\
\hline $\begin{array}{l}\text { Principle } 2 \text {. The Regulator should be operationally } \\
\text { independent and accountable in the exercise of its } \\
\text { functions and powers. }\end{array}$ & $\begin{array}{l}\text { The four regulatory agencies work under a robust } \\
\text { framework of independence from the government, } \\
\text { both operational and financial. At the same time } \\
\text { there are mechanisms for accountability to the } \\
\text { Government via the MoF, and decisions of the } \\
\text { regulatory agencies are also subject to judicial } \\
\text { review. The existence of part time members on the } \\
\text { boards of the agencies that have a commission } \\
\text { structure, and in particular the possibility currently } \\
\text { allowed by the legal framework that they can be } \\
\text { directors of issuers and registrants poses concerns } \\
\text { vis-à-vis commercial interests. In practice, such } \\
\text { concerns are mitigated by the selection processes in } \\
\text { place in the respective jurisdictions, which looks at }\end{array}$ \\
\hline
\end{tabular}




\begin{tabular}{|c|c|}
\hline & $\begin{array}{l}\text { skills, integrity and confidentiality issues and the } \\
\text { existence and application of strong conflict of } \\
\text { interest rules which require members to recuse } \\
\text { themselves from decisions where they face a } \\
\text { conflict. In practice the effects of the recusal range } \\
\text { from abstaining from voting in a decision, where } \\
\text { the conflict is more remote to not receiving any } \\
\text { document nor participating at all in the decision, } \\
\text { where the conflict is more direct }\end{array}$ \\
\hline $\begin{array}{l}\text { Principle } 3 . \text { The Regulator should have adequate } \\
\text { powers, proper resources and the capacity to } \\
\text { perform its functions and exercise its powers. }\end{array}$ & $\begin{array}{l}\text { The four regulatory agencies have robust powers to } \\
\text { regulate and supervise the markets, including } \\
\text { rulemaking authority, registration, recognition and } \\
\text { designation authority, power to request } \\
\text { information, and conduct on-site inspections and } \\
\text { the power to impose administrative sanctions and } \\
\text { to pursue quasi-criminal offenses. Resources in the } \\
\text { four agencies have increased over time to respond } \\
\text { to market growth and the growing regulatory } \\
\text { perimeter. The agencies should continue their } \\
\text { efforts to recruit staff with specialized expertise. }\end{array}$ \\
\hline $\begin{array}{l}\text { Principle } 4 \text {. The Regulator should adopt clear and } \\
\text { consistent regulatory processes. }\end{array}$ & $\begin{array}{l}\text { Carry from the } 2007 \text { assessment } \\
\text { The regulatory agencies are subject to a high degree } \\
\text { of transparency including public consultation } \\
\text { regarding regulations and policy statements. They } \\
\text { are active on investor education. }\end{array}$ \\
\hline $\begin{array}{l}\text { Principle } 5 \text {. The staff of the Regulator should } \\
\text { observe the highest professional standards, } \\
\text { including appropriate standards of confidentiality. }\end{array}$ & $\begin{array}{l}\text { Carry from the } 2007 \text { assessment } \\
\text { The regulatory agencies have developed codes of } \\
\text { ethics. Reporting obligations on investment activities } \\
\text { are in place as well as mechanisms to monitor } \\
\text { compliance. }\end{array}$ \\
\hline $\begin{array}{l}\text { Principle } 6 . \text { The Regulator should have or } \\
\text { contribute to a process to monitor, mitigate and } \\
\text { manage systemic risk, appropriate to its mandate. }\end{array}$ & $\begin{array}{l}\text { The securities regulators have developed a } \\
\text { definition of systemic risk, and a methodology to } \\
\text { identify and monitor such risks. There are also } \\
\text { mechanisms in place for accountability, including } \\
\text { follow up and periodic reporting on progress. } \\
\text { However the analysis is still mostly qualitative, and } \\
\text { data availability is currently a challenge. The HoA } \\
\text { has served as a forum to engage in systemic risk } \\
\text { discussions; however there is a need to deepen } \\
\text { such coordination, in particular in connection with }\end{array}$ \\
\hline
\end{tabular}




\begin{tabular}{|c|c|}
\hline & crisis management. \\
\hline $\begin{array}{l}\text { Principle } 7 . \text { The Regulator should have or } \\
\text { contribute to a process to review the perimeter of } \\
\text { regulation regularly. }\end{array}$ & $\begin{array}{l}\text { The Committee system of the CSA is the main } \\
\text { mechanism to identify emerging risks; and their } \\
\text { work is supported by internal arrangements within } \\
\text { the provincial regulatory agencies-some of which } \\
\text { have established emerging risk committees. } \\
\text { However, the analysis is currently mainly qualitative, } \\
\text { and data availability is a challenge. }\end{array}$ \\
\hline $\begin{array}{l}\text { Principle } 8 \text {. The Regulator should seek to ensure } \\
\text { that conflicts of interest and misalignment of } \\
\text { incentives are avoided, eliminated, disclosed or } \\
\text { otherwise managed. }\end{array}$ & $\begin{array}{l}\text { Several areas have been identified where important } \\
\text { conflict of interest exist, including trailing } \\
\text { commissions. The authorities are currently analyzing } \\
\text { regulatory actions. }\end{array}$ \\
\hline $\begin{array}{l}\text { Principle 9. Where the regulatory system makes } \\
\text { use of Self-Regulatory Organizations (SROs) that } \\
\text { exercise some direct oversight responsibility for } \\
\text { their respective areas of competence, such SROs } \\
\text { should be subject to the oversight of the } \\
\text { Regulator and should observe standards of } \\
\text { fairness and confidentiality when exercising } \\
\text { powers and delegated responsibilities. }\end{array}$ & $\begin{array}{l}\text { Canada makes extensive use of SROs both for the } \\
\text { supervision of securities intermediaries (investment } \\
\text { dealers and mutual fund dealers and their } \\
\text { representatives), as well as for market surveillance. } \\
\text { SROs are subject to a strong framework of } \\
\text { oversight, starting with the recognition process, and } \\
\text { including approval of their rules, periodic reporting } \\
\text { and on-site inspections. However, a few challenges } \\
\text { remain in connection with their governance } \\
\text { structures vis-à-vis their ability to manage conflict } \\
\text { of interest. }\end{array}$ \\
\hline $\begin{array}{l}\text { Principle } 10 . \text { The Regulator should have } \\
\text { comprehensive inspection, investigation and } \\
\text { surveillance powers. }\end{array}$ & $\begin{array}{l}\text { Carry from the } 2007 \text { assessment } \\
\text { The regulatory agencies have broad investigative and } \\
\text { surveillance powers over regulated entities. In } \\
\text { particular, they can conduct on-site inspections, } \\
\text { including of books and records without prior notice; } \\
\text { obtain books and records and request data or } \\
\text { information without the need for a judicial action; } \\
\text { and supervise exchanges and regulated trading } \\
\text { systems. }\end{array}$ \\
\hline $\begin{array}{l}\text { Principle } 11 \text {. The Regulator should have } \\
\text { comprehensive enforcement powers. }\end{array}$ & $\begin{array}{l}\text { Carry from the } 2007 \text { assessment } \\
\text { The regulatory agencies have broad enforcement } \\
\text { powers. These include the power to seek injunctions; } \\
\text { bring an application for civil proceedings; order the } \\
\text { suspension of trading and the freezing of assets; } \\
\text { compel information, documents, records and } \\
\text { testimony from third parties (non-regulated entities) } \\
\text { in the course of their investigations; impose }\end{array}$ \\
\hline
\end{tabular}




\begin{tabular}{|c|c|}
\hline & $\begin{array}{l}\text { administrative sanctions; seek quasi criminal actions; } \\
\text { and refer matters to the criminal authorities. }\end{array}$ \\
\hline $\begin{array}{l}\text { Principle } 12 \text {. The regulatory system should ensure } \\
\text { an effective and credible use of inspection, } \\
\text { investigation, surveillance and enforcement } \\
\text { powers and implementation of an effective } \\
\text { compliance program. }\end{array}$ & $\begin{array}{l}\text { Intermediaries are subject to both off site } \\
\text { monitoring and on-site inspections. The on-site } \\
\text { inspection programs developed by the securities } \\
\text { regulatory agencies and the SROs follow a risk- } \\
\text { based approach. This approach has resulted in a } \\
\text { more focused use of on-site inspections by the } \\
\text { regulatory agencies with the largest populations } \\
\text { Enforcement by the four provincial regulators } \\
\text { analyzed has significantly improved over time and is } \\
\text { currently robust. The SROs are taking important } \\
\text { steps to ensure timely response by firms to their } \\
\text { compliance reports (MFDA) as well as to strengthen } \\
\text { the nexus between compliance reviews and the } \\
\text { enforcement function (IIROC). Important challenges } \\
\text { remain in connection with enforcement by the } \\
\text { criminal enforcement authorities. Although, the } \\
\text { regulatory agencies have enhanced coordination } \\
\text { and taken concrete steps to get the criminal } \\
\text { authorities more engaged, the results are mixed, } \\
\text { with progress being achieved only in some of the } \\
\text { largest jurisdictions. }\end{array}$ \\
\hline $\begin{array}{l}\text { Principle 13. The Regulator should have authority } \\
\text { to share both public and non-public information } \\
\text { with domestic and foreign counterparts. }\end{array}$ & $\begin{array}{l}\text { Carry from the } 2007 \text { assessment } \\
\text { The regulatory agencies have broad authority to } \\
\text { share information with both domestic and foreign } \\
\text { regulators and have done so even in cases where no } \\
\text { memorandum of understanding (MoU) was in place. }\end{array}$ \\
\hline $\begin{array}{l}\text { Principle 14. Regulators should establish } \\
\text { information sharing mechanisms that set out } \\
\text { when and how they will share both public and } \\
\text { non-public information with their domestic and } \\
\text { foreign counterparts. }\end{array}$ & $\begin{array}{l}\text { Carry from the } 2007 \text { assessment } \\
\text { The four largest regulatory agencies are signatories } \\
\text { of the IOSCO MMoU. They also have bilateral MoUs, } \\
\text { including a MoU with the U.S. Securities Exchange } \\
\text { Commission and the U.S. Commodity Futures } \\
\text { Trading Commission. }\end{array}$ \\
\hline $\begin{array}{l}\text { Principle } 15 . \text { The regulatory system should allow } \\
\text { for assistance to be provided to foreign } \\
\text { Regulators who need to make inquiries in the } \\
\text { discharge of their functions and exercise of their } \\
\text { powers. }\end{array}$ & $\begin{array}{l}\text { Carry from the } 2007 \text { assessment } \\
\text { The regulatory agencies have authority to assist } \\
\text { foreign regulators in obtaining information that is } \\
\text { not in their files. }\end{array}$ \\
\hline
\end{tabular}




\begin{tabular}{|c|c|}
\hline $\begin{array}{l}\text { Principle } 16 . \text { There should be full, accurate and } \\
\text { timely disclosure of financial results, risk and other } \\
\text { information that is material to investors' decisions. }\end{array}$ & $\begin{array}{l}\text { Carry from the } 2007 \text { assessment } \\
\text { Issuers are subject to disclosure requirements at the } \\
\text { moment of authorization and on an ongoing basis. }\end{array}$ \\
\hline $\begin{array}{l}\text { Principle } 17 . \text { Holders of securities in a company } \\
\text { should be treated in a fair and equitable manner. }\end{array}$ & $\begin{array}{l}\text { Carry from the } 2007 \text { assessment } \\
\text { The framework for corporations addresses issues of } \\
\text { shareholders' rights, including notice of meetings; } \\
\text { and special majorities for the approval of major } \\
\text { changes. A mandatory tender offer is required for the } \\
\text { acquisition of control of a listed company. }\end{array}$ \\
\hline $\begin{array}{l}\text { Principle 18. Accounting standards used by issuers } \\
\text { to prepare financial statements should be of a } \\
\text { high and internationally acceptable quality. }\end{array}$ & $\begin{array}{l}\text { Carry from the } 2007 \text { assessment } \\
\text { Issuers are required to submit financial information } \\
\text { in accordance with Canadian Generally Accepted } \\
\text { Accounting Principles (GAAPs). Audits have to be } \\
\text { conducted in accordance with Canadian Accounting } \\
\text { Standards (Canadian AS). }\end{array}$ \\
\hline $\begin{array}{l}\text { Principle } 19 \text {. Auditors should be subject to } \\
\text { adequate levels of oversight. }\end{array}$ & $\begin{array}{l}\text { Auditing firms of reporting issuers are subject to } \\
\text { the oversight of CPAB, which is a body independent } \\
\text { from the audit profession. CPAB has put in place a } \\
\text { robust plan of on-site inspections. CPAB mainly } \\
\text { uses recommendations-which implementation is } \\
\text { mandatory-to address deficiencies found, and } \\
\text { currently it cannot impose fines. In addition, there } \\
\text { are limitations on the level of transparency that } \\
\text { CPAB can give to its enforcement decisions, which } \\
\text { can impact their deterrent effect. There are also } \\
\text { limitations in the information that CPAB can share } \\
\text { with audit committees, and the regulatory agencies. } \\
\text { Finally, not all provincial statutes provide CPAB with } \\
\text { legal protection and non- compellability. }\end{array}$ \\
\hline $\begin{array}{l}\text { Principle } 20 \text {. Auditors should be independent of } \\
\text { the issuing entity that they audit. }\end{array}$ & $\begin{array}{l}\text { The codes of conduct of the provincial accounting } \\
\text { bodies, to which all auditors must abide, contain } \\
\text { robust provisions on independence. There are } \\
\text { several mechanisms in place to monitor compliance } \\
\text { with independence requirements, starting at the } \\
\text { firm level, and including the audit committees for } \\
\text { reporting issuers (i.e. issuers of public offering), and } \\
\text { CPAB's reviews. }\end{array}$ \\
\hline $\begin{array}{l}\text { Principle } 21 \text {. Audit standards should be of a high } \\
\text { and internationally acceptable quality. }\end{array}$ & $\begin{array}{l}\text { Carry from the } 2007 \text { assessment } \\
\text { Issuers are required to submit financial information }\end{array}$ \\
\hline
\end{tabular}




\begin{tabular}{|c|c|}
\hline & $\begin{array}{l}\text { in accordance with Canadian Generally Accepted } \\
\text { Accounting Principles (GAAPs). Audits have to be } \\
\text { conducted in accordance with Canadian Accounting } \\
\text { Standards (Canadian AS). }\end{array}$ \\
\hline $\begin{array}{l}\text { Principle } 22 \text {. Credit rating agencies should be } \\
\text { subject to adequate levels of oversight. The } \\
\text { regulatory system should ensure that credit rating } \\
\text { agencies whose ratings are used for regulatory } \\
\text { purposes are subject to registration and ongoing } \\
\text { supervision. }\end{array}$ & $\begin{array}{l}\text { There is a designation process in place for credit } \\
\text { rating agencies who wish to have their ratings used } \\
\text { for regulatory purposes. The requirements for } \\
\text { designation are built around the IOSCO Code of } \\
\text { Conduct. The designation process followed by the } \\
\text { principal regulator was robust. However, a system } \\
\text { of on-site inspections is not yet in place. }\end{array}$ \\
\hline $\begin{array}{l}\text { Principle } 23 \text {. Other entities that offer investors } \\
\text { analytical or evaluative services should be subject } \\
\text { to oversight and regulation appropriate to the } \\
\text { impact their activities have on the market or the } \\
\text { degree to which the regulatory system relies on } \\
\text { them. }\end{array}$ & $\begin{array}{l}\text { Sell side analysts and more generally investment } \\
\text { dealers are subject to robust conflict of interest } \\
\text { rules in connection with research, which were } \\
\text { developed by IIROC. In addition, technical reports } \\
\text { for mining issuers and valuations of certain type of } \\
\text { transactions concerning issuers are also subject to a } \\
\text { framework aimed at addressing potential conflict of } \\
\text { interest, including the need that they be prepared } \\
\text { by qualified professionals. }\end{array}$ \\
\hline $\begin{array}{l}\text { Principle } 24 \text {. The regulatory system should set } \\
\text { standards for the eligibility, governance, } \\
\text { organization and operational conduct of those } \\
\text { who wish to market or operate a collective } \\
\text { investment scheme. }\end{array}$ & $\begin{array}{l}\text { Operators of CIS (IFMs) as well as their distributors } \\
\text { and advisers are subject to registration. Registration } \\
\text { requirements are robust In the case of shareholders } \\
\text { and directors the system does not require explicitly } \\
\text { that they be fit and proper; however information on } \\
\text { integrity, solvency and proficiency must be } \\
\text { provided by them at the moment of registration } \\
\text { and on an going basis and the regulators can seek } \\
\text { substantively similar outcomes by way of denying } \\
\text { registration of the firm, imposing conditions or } \\
\text { even suspending the firm if they believe that the } \\
\text { lack of qualifications of a shareholder or director } \\
\text { may cause harm to investors. The registration } \\
\text { process has important differences across provinces, } \\
\text { as in some provinces the review of internal controls } \\
\text { and risk management is left to a later stage through } \\
\text { the on-site inspection program. IFMs are subject to } \\
\text { off-site monitoring and on-site inspections. On-site } \\
\text { inspection programs are developed based on a risk } \\
\text { based assessment by the regulators. While } \\
\text { adequate, the current approach has resulted in a }\end{array}$ \\
\hline
\end{tabular}




\begin{tabular}{|c|c|}
\hline & $\begin{array}{l}\text { more focused use of on-site inspections in the } \\
\text { provinces with the largest populations. }\end{array}$ \\
\hline $\begin{array}{l}\text { Principle } 25 \text {. The regulatory system should provide } \\
\text { for rules governing the legal form and structure of } \\
\text { collective investment schemes and the } \\
\text { segregation and protection of client assets. }\end{array}$ & $\begin{array}{l}\text { Partially carry from the } 2007 \text { assessment } \\
\text { The legal form and structure of CIS have to be } \\
\text { disclosed in the prospectus, along with investors' } \\
\text { rights. There are provisions on separation of assets. } \\
\text { Aspects reassessed in } 2013 \\
\text { CIS that are offered to the public must have a } \\
\text { custodian, which can only be a bank or a trust } \\
\text { company. Custody by a related party is not } \\
\text { prohibited however there are safeguards in place to } \\
\text { mitigate the potential conflict, including the fact } \\
\text { that custodians are themselves regulated entities, } \\
\text { the obligation of all CIS to have an IRC which must } \\
\text { review all transactions involving conflict of interest, } \\
\text { and disclosure to investors. }\end{array}$ \\
\hline $\begin{array}{l}\text { Principle } 26 \text {. Regulation should require disclosure, } \\
\text { as set forth under the principles for issuers, which } \\
\text { is necessary to evaluate the suitability of a } \\
\text { collective investment scheme for a particular } \\
\text { investor and the value of the investor's interest in } \\
\text { the scheme. }\end{array}$ & $\begin{array}{l}\text { Carry from the } 2007 \text { assessment } \\
\text { CIS are subject to disclosure obligations at the } \\
\text { moment of authorization and on an ongoing basis. } \\
\text { The regulatory agencies have developed a system to } \\
\text { review prospectuses. A continuous obligations review } \\
\text { system has been implemented recently. }\end{array}$ \\
\hline $\begin{array}{l}\text { Principle } 27 . \text { Regulation should ensure that there } \\
\text { is a proper and disclosed basis for asset valuation } \\
\text { and the pricing and the redemption of units in a } \\
\text { collective investment scheme. }\end{array}$ & $\begin{array}{l}\text { Carry from the } 2007 \text { assessment } \\
\text { CIS are required to value their portfolios at fair value. } \\
\text { There are rules for disclosure of prices, subscription } \\
\text { and redemption, and best practice regarding pricing } \\
\text { errors }\end{array}$ \\
\hline $\begin{array}{l}\text { Principle } 28 \text {. Regulation should ensure that hedge } \\
\text { funds and/or hedge funds managers/advisers are } \\
\text { subject to appropriate oversight. }\end{array}$ & $\begin{array}{l}\text { Operators of HFs are subject to registration, as any } \\
\text { other category of IFM. HFs themselves are not } \\
\text { subject to registration. The agencies have sufficient } \\
\text { powers to require information from IFMs of HFs and } \\
\text { to share it both domestically and internationally. } \\
\text { IFMs of HFs are subject to the general supervision } \\
\text { program of the securities regulatory agencies, } \\
\text { which includes off site monitoring and on-site } \\
\text { inspections. In addition, the agencies have } \\
\text { conducted thematic reviews on the HFs themselves. }\end{array}$ \\
\hline
\end{tabular}




\begin{tabular}{|c|c|}
\hline $\begin{array}{l}\text { Principle 29. Regulation should provide for } \\
\text { minimum entry standards for market } \\
\text { intermediaries. }\end{array}$ & $\begin{array}{l}\text { Firms that provide investment services are required } \\
\text { to register. Registration requirements are based on } \\
\text { fit and proper criteria. As explained in Principle } 24 \\
\text { shareholders and directors are not explicitly } \\
\text { required to be fit and proper, but they are required } \\
\text { to submit information to this regard and there are } \\
\text { remedies that the agencies can seek if the lack of fit } \\
\text { and proper requirements of a shareholder or } \\
\text { director can cause harm to investors. Also as } \\
\text { explained in Principle } 24 \text { the processes for } \\
\text { reviewing applications for firm registration varies } \\
\text { across provinces. }\end{array}$ \\
\hline $\begin{array}{l}\text { Principle } 30 . \text { There should be initial and ongoing } \\
\text { capital and other prudential requirements for } \\
\text { market intermediaries that reflect the risks that } \\
\text { the intermediaries undertake. }\end{array}$ & $\begin{array}{l}\text { Capital requirements for all types of intermediaries } \\
\text { are based on a net capital formula, although } \\
\text { differences exist mainly due to the differences in } \\
\text { activities that each category is authorized to } \\
\text { conduct. However, a unique feature of the Canadian } \\
\text { system is that investment dealers are allowed to use } \\
\text { uninvested cash from clients, which arguably } \\
\text { constitute deposits. The use of such funds is subject } \\
\text { to certain prudential requirements, some of them } \\
\text { already imbedded in the capital formula, as well as } \\
\text { additional provisions including a leverage ratio, and } \\
\text { the fact that IDs must contribute to a compensation } \\
\text { fund. The analysis conducted as a result of MF } \\
\text { Global insolvency shows the need to strengthen } \\
\text { such prudential requirements so that they } \\
\text { adequately capture the risks of such "authorization" } \\
\text { and therefore ensure adequate investor protection } \\
\text { as well as smooth winding down of an ID. }\end{array}$ \\
\hline $\begin{array}{l}\text { Principle } 31 . \text { Market intermediaries should be } \\
\text { required to establish an internal function that } \\
\text { delivers compliance with standards for internal } \\
\text { organization and operational conduct, with the } \\
\text { aim of protecting the interests of clients and their } \\
\text { assets and ensuring proper management of risk, } \\
\text { through which management of the intermediary } \\
\text { accepts primary responsibility for these matters. }\end{array}$ & $\begin{array}{l}\text { Securities intermediaries are required to have in } \\
\text { place a system of compliance that covers both } \\
\text { internal controls and risk management and } \\
\text { compliance with laws and regulations. The firms are } \\
\text { also required to have in place appropriate policies } \\
\text { and procedures to deal with conflicts of interest. In } \\
\text { practice, the sole proprietorship feature of the bulk } \\
\text { of securities firms may pose challenges to the } \\
\text { implementation of robust internal controls and risk } \\
\text { management. There are appropriate rules on fair } \\
\text { dealing, segregation, know your customer and } \\
\text { suitability, and customer information. Intermediaries }\end{array}$ \\
\hline
\end{tabular}




\begin{tabular}{|c|c|}
\hline & $\begin{array}{l}\text { are subject to off-site monitoring and on-site } \\
\text { inspections. The program for on-site inspections is } \\
\text { risk based, and overall can be considered adequate. } \\
\text { However in the provinces with the largest } \\
\text { populations it has resulted in a more focused use of } \\
\text { on-site inspections. }\end{array}$ \\
\hline $\begin{array}{l}\text { Principle } 32 \text {. There should be procedures for } \\
\text { dealing with the failure of a market intermediary } \\
\text { in order to minimize damage and loss to investors } \\
\text { and to contain systemic risk. }\end{array}$ & $\begin{array}{l}\text { There are early warning systems in place for IDs and } \\
\text { MFDs. For the rest of the intermediaries there are } \\
\text { also basic arrangements in place that allow the } \\
\text { regulators to monitor their solvency, including } \\
\text { quarterly reporting and notification of capital } \\
\text { shortfalls. Currently there is no comprehensive } \\
\text { protocol to deal with the insolvency of securities } \\
\text { firms; in particular a large ID; but a crisis } \\
\text { management group was constituted recently, as a } \\
\text { result of lessons learned from the insolvency of MF } \\
\text { Global Canada. }\end{array}$ \\
\hline $\begin{array}{l}\text { Principle } 33 \text {. The establishment of trading systems } \\
\text { including securities exchanges should be subject } \\
\text { to regulatory authorization and oversight. }\end{array}$ & $\begin{array}{l}\text { Carry from the } 2007 \text { assessment } \\
\text { Exchanges are subject to an authorization regime } \\
\text { based on eligibility criteria that include integrity, } \\
\text { financial viability, and capacity. ATS are regulated as } \\
\text { dealers; however the framework allows the } \\
\text { regulatory agencies to regulate them as an exchange } \\
\text { once they reach a certain threshold. }\end{array}$ \\
\hline $\begin{array}{l}\text { Principle } 34 \text {. There should be ongoing regulatory } \\
\text { supervision of exchanges and trading systems } \\
\text { which should aim to ensure that the integrity of } \\
\text { trading is maintained through fair and equitable } \\
\text { rules that strike an appropriate balance between } \\
\text { the demands of different market participants. }\end{array}$ & $\begin{array}{l}\text { IIROC and the derivatives exchanges have } \\
\text { developed robust automated systems that allow for } \\
\text { both real time and post trade surveillance. There is } \\
\text { a MoU between IIROC and MX that seeks to ensure } \\
\text { collaboration in cross markets surveillance, and in } \\
\text { practice referrals do take place. An automated } \\
\text { system to further enhance cross market surveillance } \\
\text { is being developed. }\end{array}$ \\
\hline $\begin{array}{l}\text { Principle } 35 . \text { Regulation should promote } \\
\text { transparency of trading. }\end{array}$ & $\begin{array}{l}\text { Equity markets are subject to robust pre-and post- } \\
\text { trade transparency requirements, including a } \\
\text { consolidated tape. While dark orders are allowed, } \\
\text { current obligations imposed on them incentivize } \\
\text { transparency. Debt markets are subject to pre and } \\
\text { post-trade transparency that appear adequate in } \\
\text { light of the current market structure. }\end{array}$ \\
\hline Principle 36 . Regulation should be designed to & Carry from the 2007 assessment \\
\hline
\end{tabular}




\begin{tabular}{|l|l|}
\hline $\begin{array}{l}\text { detect and deter manipulation and other unfair } \\
\text { trading practices. }\end{array}$ & $\begin{array}{l}\text { The Universal Market Integrity Rules (UMIR) contain } \\
\text { provisions that prohibit market manipulation and } \\
\text { other unfair practices. Similarly, the MX also has } \\
\text { trading rules that cover manipulative or deceptive } \\
\text { methods of trading. Practices that RS or MX could } \\
\text { not pursue-such as insider trading-are in the } \\
\text { framework of the regulatory agencies. Some also } \\
\text { constitute criminal offenses (for example insider } \\
\text { trading). }\end{array}$ \\
\hline $\begin{array}{l}\text { Principle 37. Regulation should aim to ensure the } \\
\text { proper management of large exposures, default } \\
\text { risk and market disruption. }\end{array}$ & $\begin{array}{l}\text { Partially carry from the 2007 assessment } \\
\text { The Canadian Depository for Securities Limited (CDS) } \\
\text { and the Canadian Derivatives Clearing Corporation } \\
\text { (CDCC) have developed mechanisms to manage } \\
\text { large exposures, including capital requirements for } \\
\text { clearing members, margins, collateral and caps on } \\
\text { the transactions that can be entered for settlement. } \\
\text { New issues assessed in 2003 } \\
\text { Mandatory buy in for failed settlement is not }\end{array}$ \\
\hline $\begin{array}{l}\text { Principle 38. Securities settlement systems and } \\
\text { rentral counterparties should be subject to } \\
\text { efficient and that they reduce systemic risk. }\end{array}$ & $\begin{array}{l}\text { required; however rules in place provide sufficient } \\
\text { incentive to ensure timely settlement. There are } \\
\text { reporting obligations in place for shortselling. }\end{array}$ \\
\hline
\end{tabular}




\section{F. Recommendations}

Table 6. Recommendation for the Implementation of the IOSCO Principles

\begin{tabular}{|c|c|}
\hline Principle & Recommended Action \\
\hline Principle 1 & $\begin{array}{l}\text { The securities regulators should continue to consider the differences that remain in } \\
\text { connection with derivatives, prospectus exemptions, registration exemptions for EMDs } \\
\text { in the northwest jurisdictions and registration of non-resident IFMs and work towards } \\
\text { achieving further harmonization. } \\
\text { The securities regulators should continue to foster convergence of supervisory } \\
\text { practices. Consideration should be given to undertaking peer reviews on a more } \\
\text { frequent basis as part of the toolkit. } \\
\text { Coordination arrangements among the provincial regulators, and the SROs, should } \\
\text { continue to be strengthened to ensure that a full view of risks is developed. By the } \\
\text { same token coordination with other financial authorities should be strengthened, } \\
\text { including crisis management, as described in Principle } 32 \text {. } \\
\text { The Canadian authorities and governments should work towards ensuring a level } \\
\text { playing field between all investment products, in particular by ensuring that } \\
\text { distribution obligations are applicable and monitored in connection with segregated } \\
\text { funds. } \\
\text { The securities regulators should continue to pursue arrangements that allow for timely } \\
\text { decision making. }\end{array}$ \\
\hline Principle 2 & $\begin{array}{l}\text { The agencies with a commission structure that have not done so should consider } \\
\text { adopting internal policies that restrict the possibility that directors of issuers and } \\
\text { registrants seat on the board.. }\end{array}$ \\
\hline Principle 3 & The regulatory agencies should continue to hire staff with specialized expertise. \\
\hline Principle 6 & $\begin{array}{l}\text { The securities regulators should continue to deepen their framework for systemic risk } \\
\text { identification by making more use of quantitative analysis. To this end, a strategy } \\
\text { towards data and resources should be devised. } \\
\text { The securities regulators should continue to work towards ensuring a two way } \\
\text { communication with the SROs. } \\
\text { Coordination arrangements with other financial authorities should be strengthened, } \\
\text { including crisis management, as described in Principle } 32 \text {. }\end{array}$ \\
\hline
\end{tabular}




\begin{tabular}{|c|c|}
\hline Principle 7 & $\begin{array}{l}\text { The securities regulators should continue to deepen their framework for emerging risk } \\
\text { identification by making more use of quantitative analysis. At the same time, the } \\
\text { assessor encourages the authorities to review whether the current decentralized } \\
\text { structure to look at risks should be further strengthened, for example, by providing } \\
\text { more structured means for accountability (as such in place for systemic risk } \\
\text { monitoring). } \\
\text { The securities regulators should continue to work towards ensuring a two way } \\
\text { communication with the SROs. In such context they should also review whether } \\
\text { stronger arrangements for identification of emerging risk are also needed at the SRO } \\
\text { level. }\end{array}$ \\
\hline Principle 8 & $\begin{array}{l}\text { The securities regulators should continue to give priority to the identification of } \\
\text { conflicts of interest. Appropriate regulatory actions should continue to be taken } \\
\text { including in connection with the areas identified in this assessment, such as trailing } \\
\text { fees. }\end{array}$ \\
\hline Principle 9 & $\begin{array}{l}\text { The securities regulators should continue to focus on governance issues on their } \\
\text { oversight of SROs. }\end{array}$ \\
\hline le 12 & $\begin{array}{l}\text { The securities regulators should continue to pursue efforts to build cooperative } \\
\text { arrangements with the criminal authorities. } \\
\text { The MFDA should continue its efforts to ensure timely response of firms with their } \\
\text { compliance reviews. } \\
\text { IIROC should continue its efforts to strengthen the nexus between their compliance } \\
\text { reviews and their enforcement function. } \\
\text { The securities regulators should continue to apply tools at their disposal to ensure } \\
\text { coordination in enforcement, including via joint investigations and adjudications, as } \\
\text { well as reciprocal orders, as necessary and appropriate. }\end{array}$ \\
\hline Principle 13 & $\begin{array}{l}\text { The } 2007 \text { assessment included the following recommendation, which was implemented } \\
\text { by the authorities: "The AMF and the Government of Québec should work together on } \\
\text { defining an efficient procedure for the approval of MoUs". This recommendation was } \\
\text { implemented". }\end{array}$ \\
\hline Principle 16 & $\begin{array}{l}\text { The } 2007 \text { assessment included the following recommendations, which were both } \\
\text { implemented. } \\
\text { "The assessor encourages the Government of Québec to give prompt approval to the new } \\
\text { framework for derivatives markets. } \\
\text { The assessor encourages all provincial regulators to expand liability to continuous } \\
\text { disclosure obligations". }\end{array}$ \\
\hline
\end{tabular}




\begin{tabular}{|c|c|}
\hline Principle 19 & $\begin{array}{l}\text { The use of different types of enforcement tools by CPAB should be kept under } \\
\text { monitoring; at the same time consideration should be given to including fines as part } \\
\text { of CPAB's toolkit, and to strengthen the transparency of disciplinary measures } \\
\text { CPAB and the securities regulators should continue to work towards achieving greater } \\
\text { sharing of information with the audit committees and the regulators. } \\
\text { Changes to the legal framework of the remaining provinces should be made to ensure } \\
\text { legal protection of CPAB staff as well as non-compellability. }\end{array}$ \\
\hline Principle 22 & $\begin{array}{l}\text { The regulatory agencies should finalize the implementation of an on-site inspection } \\
\text { program for DROs. }\end{array}$ \\
\hline Princ & $\begin{array}{l}\text { The regulatory agencies, in particular those with the largest population of } \\
\text { intermediaries, should continue to monitor the efficacy of the risk-based approach } \\
\text { with a view towards enhancing the use of on-site inspections (on individual firms } \\
\text { and/or thematic inspections) } \\
\text { The regulatory agencies should consider to explicitly require integrity and solvency } \\
\text { requirements for shareholders and integrity, solvency and experience requirements for } \\
\text { directors so that the regulatory authorities have an indisputable authority to refuse } \\
\text { shareholders or directors when such requirements are not met. }\end{array}$ \\
\hline Principle 25 & $\begin{array}{l}\text { The } 2007 \text { assessment included the following recommendation: "The provincial } \\
\text { regulators should require all CIS to have a custodian. Approval of the proposed National } \\
\text { Instrument } 41-101 \text { would achieve this goal". This recommendation was implemented as } \\
\text { all CIS that offered securities to the public are required now to have a custodian. } \\
\text { Consideration should be given to extending custody requirements to all CIS. }\end{array}$ \\
\hline Principle 29 & $\begin{array}{l}\text { The regulatory agencies should consider to explicitly require integrity and solvency } \\
\text { requirements for shareholders and integrity, solvency and experience requirements for } \\
\text { directors so that the regulatory authorities have an indisputable authority to refuse } \\
\text { shareholders or directors when such requirements are not met. } \\
\text { The regulatory authorities are encouraged to follow up on the differences in } \\
\text { requirements of the PM and EMD categories versus the ID and MFDA categories, and } \\
\text { determine the extent to which in light of the findings from their targeted review it is } \\
\text { advisable that they be subject to similar requirements in connection with the SRO } \\
\text { membership and the contribution to a contingency fund. } \\
\text { The AMF should continue to work towards harmonization of the MFD category. }\end{array}$ \\
\hline Principle 30 & $\begin{array}{l}\text { The prudential framework for the use of uninvested cash from clients should be } \\
\text { strengthened to ensure that risks are adequately captured. }\end{array}$ \\
\hline
\end{tabular}




\begin{tabular}{|c|c|}
\hline Principle 31 & $\begin{array}{l}\text { The regulatory agencies, in particular those with the largest population of } \\
\text { intermediaries, should continue to monitor the efficacy of the risk-based approach } \\
\text { with a view towards enhancing the use of on-site inspections (on individual firms } \\
\text { and/or thematic inspections). }\end{array}$ \\
\hline Principle 32 & $\begin{array}{l}\text { Crisis management arrangements should become more institutionalized, a specific } \\
\text { protocol establishing the roles of each party should be developed and simulation } \\
\text { exercises be included as a regular plan of the crisis management framework. In } \\
\text { addition, given that the largest IDs are part of banking groups it is important that } \\
\text { coordination arrangements include OSFI. } \\
\text { The securities regulators should work towards implementing portability requirements. }\end{array}$ \\
\hline Principle 34 & $\begin{array}{l}\text { The } 2007 \text { assessment included the following recommendation, which was } \\
\text { implemented: "The MoU between RS and MX should be finalized". } \\
\text { The securities regulators should continue to give priority to the development of an } \\
\text { automated system for cross markets surveillance. }\end{array}$ \\
\hline Principle 35 & $\begin{array}{l}\text { The } 2007 \text { assessment included the following recommendation, which has not been } \\
\text { implemented: "The provincial regulators should explore whether additional transparency } \\
\text { is needed in the government debt market". } \\
\text { The authorities in coordination with IIROC should continue to review the need to } \\
\text { establish a minimum size for dark orders. } \\
\text { Consideration should be given to expanding post-trade transparency requirements in } \\
\text { the corporate bond market. In addition the authorities should consider post trade } \\
\text { transparency for the government bond market. }\end{array}$ \\
\hline
\end{tabular}

\section{G. Authorities' Response}

86. The Canadian securities regulators participating in the FSAP (the regulators) welcome the IMF's review of the Canadian framework for the regulation and supervision of securities markets. We appreciate the significant time and effort the IMF Mission Team dedicated to complete the assessment, as well as their thoroughness and professionalism in assessing our system against the IOSCO Principles.

87. We are pleased that the IMF recognizes and concludes that "the Canadian framework for the regulation and supervision of securities markets demonstrates a high level of implementation of the IOSCO Principles." In particular, we are pleased that the IMF recognizes and concludes that in a few areas, such as enforcement, the securities regulators have powers that can be considered at the forefront of securities regulation.

88. The IMF's recommendations in its 2007 FSAP were carefully considered and we continue to develop and implement reform initiatives consistent with our G-20 commitments and with IOSCO reform initiatives, policies and standards. 
89. We will carefully consider the findings and recommendations from this FSAP, and we will continue to improve our oversight and supervision of the securities markets. In fact, several of the IMF's recommendations are in line with a number of projects we have underway and help to highlight the importance of this work.

90. We would also like to take this opportunity to comment on certain other aspects of the assessment, as detailed below:

\section{Additional Comments}

\section{On-site Inspections}

91. Over the years, the regulators have devised and implemented an on-site inspection program of regulated firms based on a comprehensive risk-based model. This approach to onsite inspections permits the regulators to efficiently and effectively supervise the conduct of regulated firms. By focusing on the firms and the areas of their operations that are considered to be the highest risk, the regulators use resources more efficiently and more effectively and are able to target problematic conduct on the part of registrants. The regulators are continuously assessing the risks posed by each regulated firm in light of all available information and reviewing the factors utilized in the risk-based model, as well as considering any other enhancements that may be made to the risk-based inspection program.

92. Given the comprehensive nature of the risk-based model, coupled with the continuous review and adjustment process, the regulators believe that the current level of on-site inspections is appropriate. As with all securities regulatory matters, the regulators will continue to assess the efficacy of the on-site inspection program and make justified adjustments as necessary.

\section{Enforcement of Criminal Laws}

93. We welcome the IMF's conclusion that there has been significant progress in enforcement by the provincial Canadian securities regulators. The regulators are also pleased that the IMF has recognized their increased efforts to support the enforcement of criminal laws by the relevant criminal authorities. While the broadly worded opinion in respect of the effectiveness of the criminal law branch of the Canadian justice system goes beyond the scope of an assessment of the securities sector, the regulators want to emphasize that cases involving criminal activity in the capital markets are in fact prosecuted. As part of regulating the capital markets efficiently and effectively, the securities regulators will continue to cooperate with the criminal authorities and assist them in pursuing their responsibilities to prosecute such matters

\section{Commentary on Supreme Court of Canada Reference}

94. The Canadian securities regulators welcomed the opportunity to provide a comprehensive description of the Canadian securities regulatory regime as part of the IMF's FSAP assessment and rating of financial market supervision against accepted international standards. In order for such assessments to be viewed as objective, it is important for the IMF to 
focus on the substantive elements of the securities regulatory regime, as opposed to constitutional and political considerations as to how the responsibilities for implementing the regime have been delineated. As such, the Canadian securities regulators feel comments respecting the observations of the Supreme Court of Canada in a constitutional matter concerning securities regulation go beyond the scope of the assessment against the IOSCO Principles. In addition, the reference to the Court's decision included in the assessment is a short excerpt of a summary and does not provide the full extent and meaning of the Court's unanimous decision.

\section{Part-time Commissioners}

95. As is evidenced by the IMF's assessment, the Canadian securities regulators take the risks attached to the existence of conflicts of interest seriously. We are pleased that the IMF recognized that we have comprehensive and robust policies for managing potential conflicts that work well, and that there is no evidence of interference.

96. In considering and addressing situations where conflicts of interest may arise, the regulators weigh the benefits and risks of permitting situations where a conflict may arise. In respect of the decision on the part of the OSC, BCSC and the ASC to permit, as a matter of law, the inclusion of part-time Commissioners who may be directors of an issuer or registrant, the regulators each engaged in a thoughtful analysis and ultimately decided that the automatic exclusion of otherwise qualified persons on this basis may be detrimental to the ability of those Commissions to effectively and efficiently regulate the capital markets. In respect of the OSC and ASC, the current inclusion of a small number of Commissioners who sit as directors of an issuer, coupled with strong conflicts of interest policies, provides a significant benefit to the collective ability of each

Commission to engage in analysis and decision-making. We also note that our conflict management policies and procedures are intended to capture all types of potential conflict situations, and are not specifically tied to a Commissioner's status as a director of a market participant.

\section{Harmonization}

\section{As a result of much hard work on the part of the Canadian securities regulators, the} Canadian securities regulatory regime is highly harmonized. The regulators recognize the benefits to the capital market of having a highly harmonized securities regulatory regime. However, each Commission has the authority to implement non-harmonized securities laws where doing so is of benefit to that jurisdiction's capital market, given the size, history and geographic realities of Canada. This is an important element and a strength of the Canadian securities regulatory regime. It permits the regulators to, in the vast majority of cases, implement harmonized securities laws while also permitting each Commission to tailor those laws, where appropriate, in order to achieve the overarching objectives of investor protection and efficiency in that capital market. The regulators will continue to ensure that highly harmonized securities laws are implemented where appropriate, but not where doing so would be to the detriment of any jurisdiction's capital market. 


\section{Direct Supervision of Shareholder and Directors of Registrants}

98. The Canadian securities regulators implemented an oversight regime for registrants that includes ongoing substantive consideration of the integrity and solvency of shareholders of registrants and of the integrity, solvency and experience of directors of registrants. Such matters are given careful consideration at the time of an application for registration and while the registrant continues to be registered. As a result of the regulators' legal authority to deny registration on such grounds, and the legal authority to attach conditions to suspend or terminate such registration, the regulators already have the requisite indisputable authority over shareholders and directors of registrants.

\section{Regulatory Regime for Portfolio Managers and Exempt Market Dealers}

99. The regulators are mindful that there may be a perception by some market participants that an unlevel "playing field" exists. However, in promoting an efficient capital market that provides robust investor protection, the regulators have advised the IMF that we must, and do, consider the differences in permitted activities, standards of care applicable to each category, scope of operations (including custody), business model, and types of clients. Such differences will result in substantively distinct, but equally balanced and fair, regulatory requirements for the affected market participants. While the regulators do not feel that, at this time, Portfolio Managers and Exempt Market Dealers should be required to become members of an SRO or should be required to contribute to a contingency fund, they will continue to assess the appropriate regulatory requirements for such entities.

\section{Conclusion}

100. We wish to thank the IMF assessor, Ms. Ana Carvajal, for her professionalism, openness and availability to discuss thoroughly all aspects of this assessment. 